\title{
Blueberry as an Attractive Functional Fruit to Prevent (Pre)Diabetes Progression
}

\author{
Sara Nunes ${ }^{1,2,3} \mathbb{D}^{D}$, Pedro Vieira ${ }^{1,2,3} \mathbb{D}^{\mathrm{D}}$, Pedro Gomes ${ }^{1,2,3,4,5}$, Sofia Domingues Viana $1,2,3,6, *$ and Flávio Reis $1,2,3, * \mathbb{D}$ \\ 1 Institute of Pharmacology \& Experimental Therapeutics \& Coimbra Institute for Clinical and Biomedical \\ Research (iCBR), Faculty of Medicine, University of Coimbra, 3000-548 Coimbra, Portugal; \\ spnunes@fmed.uc.pt (S.N.); pedromdvieira96@gmail.com (P.V.); pgomes70@gmail.com (P.G.) \\ 2 Center for Innovative Biomedicine and Biotechnology (CIBB), University of Coimbra, \\ 3004-504 Coimbra, Portugal \\ 3 Clinical Academic Center of Coimbra (CACC), 3004-504 Coimbra, Portugal \\ 4 Department of Biomedicine, Faculty of Medicine, University of Porto, 4200-450 Porto, Portugal \\ 5 CINTESIS-Center for Health Technology and Services Research, University of Porto, \\ 4200-450 Porto, Portugal \\ 6 Pharmacy/Biomedical Laboratory Sciences, Polytechnic Institute of Coimbra, ESTESC-Coimbra \\ Health School, 3046-854 Coimbra, Portugal \\ * Correspondence: sofia.viana@uc.pt (S.D.V.); freis@fmed.uc.pt (F.R.)
}

Citation: Nunes, S.; Vieira, P.; Gomes, P.; Viana, S.D.; Reis, F. Blueberry as an Attractive Functional Fruit to Prevent (Pre)Diabetes Progression. Antioxidants 2021, 10, 1162. https:// doi.org/10.3390/antiox10081162

Academic Editors: Silvia M. Arribas and Maria Angeles Martín-Cabrejas

Received: 16 June 2021

Accepted: 19 July 2021

Published: 22 July 2021

Publisher's Note: MDPI stays neutra with regard to jurisdictional claims in published maps and institutional affiliations.

Copyright: (c) 2021 by the authors. Licensee MDPI, Basel, Switzerland. This article is an open access article distributed under the terms and conditions of the Creative Commons Attribution (CC BY) license (https:// creativecommons.org/licenses/by/ $4.0 /)$.

\begin{abstract}
Prediabetes, a subclinical impairment between euglycemia and hyperglycemia, is a risk factor for the development of type 2 diabetes mellitus (T2DM) and associated micro- and macrovascular complications. Lifestyle therapy, the first-line treatment of prediabetes, includes physical exercise and dietary regimens enriched in phytochemicals with health-related properties. Blueberries (Vaccinium spp.), given their pleasant taste and great abundance in beneficial phytochemicals, have gained public interest all over the world. Along with a high antioxidant activity, this functional fruit is also well-recognized due to its hypoglycemic and insulin-sensitizing effects and has been recommended for overt T2DM management. Yet blueberries target several other pathophysiological traits, namely gut microbiota dysbiosis and hepatic dysmetabolism, that ensue when prediabetes begins and for which pharmacological interventions tend to be delayed. In this work, we revisited preclinical data from in vitro assays, animal models and human studies, aiming to disclose the potential mechanisms by which blueberries may be a fruitful source of phytochemicals able to prevent (pre)diabetes progression. Collectively, future efforts should focus on longer-term studies with standardized interventions and readouts, particularly in humans, that will hopefully bring more robust evidence and concrete guidance for blueberries' effective use in prediabetes.
\end{abstract}

Keywords: blueberries; antioxidants; prediabetes; hepatic dysmetabolism; gut microbiota dysbiosis

\section{Introduction}

The type 2 diabetes mellitus (T2DM) epidemic is a major public health concern [1]. According to the International Diabetes Federation (IDF) estimates, 463 millions of people are living with diabetes globally, and it is projected to rise to 700 million by $2045[2,3]$. Paralleling this daunting scenario, prediabetes (also referred as intermediate hyperglycemia by the World Health Organization (WHO) [4] is also an increasingly common condition, characterized by blood glucose levels above the normal range but below diabetes diagnostic thresholds, and typically defined as a state of impaired fasting glucose (IFG) and/or impaired glucose tolerance (IGT). While the IDF has no data about the prevalence of IFG, 373 million people worldwide are estimated to have IGT, a number that is predicted to increase to 548 million by 2045 [2,3].

Although the prevalence of prediabetes varies according to the criteria used for diagnosis (WHO vs. American Diabetes Association, ADA) and the study population, it is consensually recognized as a risk state for T2DM development [5]. In fact, both insulin 
resistance and impaired $\beta$-cell function, which are disease hallmarks and early pathophysiological mechanisms, are responsible for the increased risk of T2DM development in patients with prediabetes [6]. Evidence points to a yearly conversion rate of 5-10\% [5,7,8], but also to cardiovascular disease (CVD) and even cancer [9,10]. Multiple genetic and environmental risk factors contribute to the progression of the disease, namely the age of the population, its genetic background, a sedentary lifestyle and poor (hypercaloric) nutritional habits $[5,11]$, collectively leading to obesity, hepatic steatosis and dyslipidemia, which are important predisposing factors for the progression of T2DM and CVD [12].

Along with peripheral insulin resistance and defects in insulin secretion, other unbalanced metabolic processes, including glucotoxicity and lipotoxicity, oxidative stress and low-grade inflammation are already evolving in the state of prediabetes [6]. In addition, recent evidence suggests that changes in gut microbiota (GM) community may also play a role in T2DM pathophysiology and impaired composition and diversity of intestinal bacterial flora (referred as dysbiosis) may actually begin at an early stage $[13,14]$.

Lifestyle therapy, including regular physical activity and diabetes-specific nutrition therapy, is the cornerstone for the early management of prediabetes due to their accessibility, cost-effectiveness as well as the limited pharmacological options with favorable safety profiles namely in the earlier stages of the disease [15-18]. Accordingly, prospective and meta-analyses studies revealed an inverse correlation between fruit and vegetable intake and the increased risk and incidence of T2DM [19-21]. Moreover, the potential beneficial roles of phytochemicals (e.g., polyphenols, prebiotic fibers) and macronutrients in plantbased diets for the prevention of metabolic syndrome and T2DM are emerging [22-24]. Among various bioactive components, epidemiological studies and randomized clinical trials clearly demonstrate that diets with high-content of polyphenolic compounds, high antioxidant capacity and prebiotic/probiotic/symbiotic activities are inversely associated with the risk of insulin resistance and (pre)diabetes progression [25-29]. Blueberries (BB), due to their enriched content in the mentioned phytochemicals, have enticed keen interest as a feasible dietary intervention for the prevention and management of (pre)diabetes. Notably, both observational and clinical studies as well as cumulative preclinical data strongly underscore $\mathrm{BB}$ as an attractive complementary strategy to halt the progression from prediabetes to overt T2DM $[20,30,31]$. Besides their well-recognized hypoglycemic and insulin-sensitizing effects [32], BB-enriched diets further improve GM homeostasis [33-35] and lessen hepatic dysmetabolism [36], two key components of (pre)diabetes evolution.

In this work, we review current evidence linking the benefits of consuming BB with hepatic- and gut-derived pathophysiological traits ensuing as soon as prediabetes. Moreover, we provide an updated analysis of the main cellular and molecular mechanisms by which BB phytochemicals are able to exert protective effects.

Studies search was performed in PubMed and ClinicalTrials.gov databases using a strategy based on keywords. Most consistent, relevant and well-designed studies (both original and literature reviews) published between 2000-2021 were included. Collectively, this work scrutinizes forefront evidence in support of BB-enriched diets as an attractive option to prevent (pre)diabetes progression.

\section{From Prediabetes to Overt Diabetes-Emphasis on Liver and Gut Paths}

The transition from a normal state to prediabetes, and then to diabetes, is the consequence of a series of pathophysiological changes, that makes the individual gradually more susceptible to the subsequent disruption of glucose homeostasis, which is mainly governed by insulin sensitivity of peripheral tissues and pancreatic $\beta$-cell function. Although there has been a significant debate in the past on whether insulin resistance or $\beta$-cell dysfunction is the primary driver in the pathogenesis of prediabetes as well as on their relative contributions to disease development [37], the current view is that both conditions dynamically influence each other and presumably synergistically exacerbate diabetes [38]. Increased peripheral insulin resistance and altered $\beta$-cell function leads to major biochemical alterations in metabolic tissues, including the liver, gut, skeletal muscle and adipose tissue, 
among other organs. Notably, oxidative stress and low-grade chronic inflammation seem to be major molecular mechanisms underlying (pre)diabetes progression, both as a cause or consequence of hyperglycemia and hyperinsulinemia [39-41].

In addition to being the main detoxifying organ of the body, the liver also plays a fundamental role in maintaining energy and metabolic homeostasis. Disturbances in hepatic glucose and lipid metabolism similarly contribute to the development of metabolic diseases, including T2DM and non-alcoholic fatty liver disease (NAFLD) [42]. Because glucose is a readily available energy source for cells, the maintenance of blood glucose levels within a relatively narrow range during periods of nutrient shortage or excess is critical for survival. The liver plays a major role in maintaining whole body glucose homeostasis by regulating several metabolic processes involved in glucose transport, oxidation, storage and production. Simultaneously, hepatic lipid metabolism encompasses fatty acid uptake, synthesis, oxidation, storage, and secretion, which requires a well-orchestrated balance between these processes, dietary intake and energy expenditure [43]. Hepatic steatosisthe hallmark and earliest feature of NAFLD_-is defined as an excessive accumulation of TGs in the cytoplasm of hepatocytes due to imbalances in the processes that maintain the normal hepatic fatty acid metabolism, and often occurs in the setting of overnutrition and obesity $[44,45]$. Collectively, the data available support the notion that hepatic steatosis is a favorable biological milieu for the development and progression of (pre)diabetes [46]. Several potential mechanisms could explain the association between hepatic steatosis and the onset of prediabetes, including increased levels of hepatokines and the presence of hepatic insulin resistance $[47,48]$.

Hundreds of trillions of microorganisms inhabit the human body, the overwhelming majority bacteria from two main phyla (Bacteroidetes and Firmicutes). This complex bacterial community is present in many body fluids and surfaces but has a huge implantation in the gastrointestinal tract (GIT), in particular in the large intestine. GM can be seen, in a way, as a supra-organism that performs crucial functions for host homeostasis (co-metabolism), which include metabolic and energetic effects, protection against pathogens, maintenance of intestinal barrier integrity and education of immune system [49,50]. Disturbances in the composition and/or functions of GM cause a situation referred as dysbiosis which has been associated not only with disorders of the GIT, but also with extra-intestinal diseases, including metabolic disorders such as obesity and diabetes [51,52]. Accumulating evidence indicates that GM is involved in host metabolism by increased energy extraction, immune system modulation, and altered lipid and glucose metabolism, all which have been demonstrated to contribute to progression to T2DM. It has been also shown that an individual's glucose response after a meal is influenced by a combination of their GM composition and host physiology $[53,54]$. Several studies have reported decline of butyrate-producing bacteria in prediabetes cohorts of distinct ethnicities [55-58], and to a greater extent in people with both IGT and IFG [13]. In sum, these findings suggest causal links between microbiota dysbiosis and glucose intolerance/progression to T2DM.

\section{Blueberries Beneficial Outcomes in (Pre)Diabetes Progression-A Multi-Modal Functional Fruit}

\subsection{BB Phytochemistry, Metabolism and Bioavailability-An Overview}

Blueberry is one of the five healthy fruits recommended by the Food and Agriculture Organization from United Nations [59]. It belongs to the genus Vaccinium of Ericaceae family which includes approximately 450 species all over the world [60]. Some examples are the well-known Vaccinium corymbosum, Vaccinium ahei, Vaccinium poasanum, Vaccinium angustifolium and Vaccinium myrtillus, the later commonly denominated as bilberries across Europe $[61,62]$. BB are characterized by their enriched nutritive composition, containing high contents of a wide diversity of biologically active components. BB chemical composition greatly varies upon the cultivar, variety, growing location, environmental conditions, plant nutrition, ripeness stage, harvest time as well as the storage conditions, making the content of each individual component highly flexible, with impact on the corresponding antioxidant profiles [63-65]. Nonetheless, BB-derived phytochemicals display a panoply 
of health-related properties beyond their antioxidant profile able to interfere with chief physiological functions [66-68]. Therefore, public interest in BB as a functional food has increased over the last years [69]. Even though the aerial parts of the shrubs are used as a folk medicine for treating metabolic diseases for years, the fruits have been constantly increasing in popularity due to their pleasant taste and organoleptic acceptance as well as the richness of their bioactive compounds [70].

$\mathrm{BB}$ fruits are low in calories $(0.046 \mathrm{kcal} / \mathrm{g}$ fresh fruit) and high in water, micronutrients (e.g., selenium, zinc, iron), dietary prebiotic fibers (3-3.5\% of fruit weight), vitamins (C, B complex, E, and A) and sugar units [e.g., glucose $(\approx 26.415 \mathrm{mg} / \mathrm{g}-46.495 \mathrm{mg} / \mathrm{g}$ fruit), fructose ( $\approx 22.682 \mathrm{mg} / \mathrm{g}-43.074 \mathrm{mg} / \mathrm{g} /$ fruit) and other osidic moieties such as ribose, rhamnose, arabinose and maltose] which are often associated with bioactive polyphenols (PP), known as heterosydic forms of PP [60,71-73]. Briefly, PP are secondary metabolites of the plants that act against ultraviolet radiation as well as in plant-microbe interactions and defense response [74]. Collectively, they encompass an aromatic ring and a minimum of two hydroxyl substituents which impact ROS scavenging ability and subsequent antioxidant effects depending on their number and position [75]. PP comprise a large family of compounds and are classified as flavonoids (including flavonols, flavanols, flavones, isoflavones, anthocyanidins and flavanones), phenolic acids (including benzoic acids, cinnamic acids and derivatives), chalcones and coumarins (intermediate in the biosynthesis of flavonoids), and lastly, polymers, including tannins and lignin [76]. PP are present in distinct parts of the BB fruit; for instance, while tannins and phenolic acids are mostly predominant in the seeds, anthocyanins and proanthocyanidins are present mainly in the fruit's skin and pulp, respectively [77]. Moreover, PP occur in vegetable cells in soluble forms (mostly localized in the cell vacuoles) as well as covalently bound with cell wall macromolecules such as structural proteins, cellulose, hemicellulose, arabinoxylans and/or pectins, collectively designated as PP insoluble forms [78]. Likewise, insoluble PP naturally present in BB fruits may become tightly linked (e.g., esther; C-C bonds) with pectin and xyloglucan, two main components of BB cell wall with prebiotic activity [35].

The biological properties of PP found in BB fruits greatly depend on effective concentrations reached in internal compartments that need to be maintained for an adequate period of time [79]. Notably, the poor bioavailability of PP present in ingested food, ranging from $1-5 \%$ of the total PP intake [80-82], is inversely correlated with their biological effects, a phenomenon stated as the low bioavailability/high bioactivity paradox [83]. Even though PP are extensively metabolized within enterocytes, colonic GM and liver by phase I/II enzymatic reactions (e.g., sulfation, methylation, glucuronidation, PP ring-fission), a wide variety of new chemical structures retaining intrinsic bioactivity along with parent compounds reach systemic circulation and are distributed to different organs and tissues, supplying efficient cellular concentrations that underpin PP efficacy [82-84].

PP physicochemical properties, their release from the food matrix during GIT digestion (bioaccessibility), cellular uptake, metabolism and transport in the circulatory system are key features that determine PP organism availability [80]. To better understand blueberry PP metabolism and pharmacokinetics, Zhong and colleagues carried out a single blind, randomized trial and followed human plasma concentrations of anthocyanins, chlorogenic acid and their metabolites over $24 \mathrm{~h}$ after oral ingestion of a wild blueberry beverage. The total bioavailability of unaltered anthocyanin compounds (displaying their original C6-C3-C6 structure) and chlorogenic acid was $1.1 \%$ and $0.2 \%$, respectively. Parent compounds and metabolites (e.g., cyanidin-, delphinidin-, petundin-glucoronide metabolites) peaked in plasma within the first $1-4 \mathrm{~h}$ post-ingestion (early phase response) and $>5 \mathrm{~h}$ after ingestion (late phase response). This bi-phasic response, probably reflective of enterohepatic circulation, may imply that different BB-derived PP and metabolites interact with GIT cells and other tissues at different times post-consumption [85]. As a matter of fact, nanostructures comprising PP-BB matrix conjugates may be protected along the transit through the GIT, a phenomenon affecting both PP absorption and cellular uptake. Likewise, in vitro gastrointestinal digestion of BB fruits underscored a high stability of 
total PP and anthocyanins during the gastric digestion step along with decreased contents upon intestinal breakdown (49\% and 15\%, respectively). This profile paralleled unchanged antioxidant activity following gastric digestion and a significant reduction $(<50 \%)$ upon digestion under intestinal conditions [80].

Furthermore, it is generally accepted that the remaining unabsorbed PP glycosides and conjugates cycled through hepatic and ileal metabolism reach the colon and modulate fermentation towards a myriad of health benefits [83]. Since small intestine lacks pectinases and cellulases, PP-dietary fibers conjugates are disrupted by colonic GM enzymes and PP metabolites liberation occurs $[78,86]$. Such metabolites display chief functions in colon health, modifying gut microbial balance towards beneficial bacteria prevalence and SCFAs production $[87,88]$. In vitro colonic digestion has also shown BB polyphenols biotransformation to syringic, cinnamic, caffeic and protocatechuic acids [80]. Likewise, microbial metabolism of blueberry PP was found to elicit positive outcomes, namely the inhibition of HT-29 colon cancer cell line proliferation as well as the repression of colonic prostanoid production and anti-inflammatory effects $[89,90]$. Overall, the in vivo bioactivity of blueberry polyphenols is strictly correlated with their absorption along the GIT as well colonic microbial metabolism [80].

\subsection{Hypoglycemic and Insulin Sensitizing Effects of BB}

A number of in vitro studies strongly suggests that BB and its bioactive phytochemicals present anti-diabetic properties. The ability of an extract from Lowbush blueberry fruit to increase pancreatic $\beta$-cell proliferation was explored in a cell culture-based bioassay, suggesting a potential capacity to restrain $\beta$-cell damage and improve insulin sensitivity [70]. Likewise, whole BB afforded pancreatic $\beta$-cell protection and prevented $\beta$-cell apoptosis and expansion in HFD-fed C57BL/6J mice [91]. Notably, a tight regulation of pancreatic islet area was observed as blueberry supplementation induced an increased number of small islets (comprising more $\beta$-cells with higher insulin) along with a decreased density of larger islets, probably delaying the overwhelmed burden of $\beta$-cells activity that pair obesity and diabetes progression [91,92]. Similar pro-proliferative effect was observed for a BB leaf extract in pancreatic MIN6 $\beta$-cells, accompanied by improved insulin signaling [68]. In vivo, this extract was able to decrease BW, plasma glucose, HbA1c, HOMA-IR, TGs and NEFAs levels in C57BL/6J mice fed with HFD [68]. These effects paralleled an increased expression of pancreatic $\beta$-cell proliferation-related genes (Ngn3, MafA, Pax4, Ins1, and Ins2) and insulin signaling genes (IRS-1, IRS-2, PIK3ca, PDK1, PKC $\varepsilon$, and GLUT-2) while FoxO1, a $\beta$-cell apoptosis-related gene, was found downregulated [68]. Similar results were observed in male Wistar rats submitted to a combined STZ+HFD paradigm of experimental T2DM [93].

Furthermore, it has been reported that BB and their bioactive compounds exhibit inhibitory activity toward pancreatic $\alpha$-amylase and intestinal $\alpha$-glucosidase, two enzymes involved in the metabolism of starch, which could lead to a delay of carbohydrate digestion and/or decreased glucose absorption [94-96]. Interestingly, in vitro studies have also highlighted that polyphenols from BB can act as strong DPP-4 inhibitors, analogous to clinically approved pharmacological options (e.g., gliptins) [97-99] (Figure 1).

Protein tyrosine phosphatase 1B (PTP1B) is another promising pharmacological target for the treatment of T2DM as it can reduce blood glucose levels by increasing insulin sensitivity [100]. Notably, Tian et al. [101] identified anthocyanins isolated from BB as selective inhibitors of PTP1B able to increase glucose consumption on HepG2 (human hepatoma) cells in a dose-dependent manner. Moreover, Nachar et al. [102] performed an in vitro study with phenolic compounds from BB juice fermented with Serratia vaccinii and observed a strong antidiabetic potential in the liver and skeletal muscle, as it was able to regulate key enzymes involved in glycogen synthesis, gluconeogenesis and skeletal muscle glucose uptake. 
$-\downarrow \alpha$-Amylase activity

- $\uparrow \beta$-Cell proliferation-related genes (Ngn3, MafA, Pax4, Ins1 and Ins2)

$-\downarrow \beta$-Cell apoptosis-related gene (FoxO1)

- $\uparrow$ Insulin signaling-related genes (IRS-1, IRS-2, PIK3ca, PDK1, PKCE, and GLUT-2
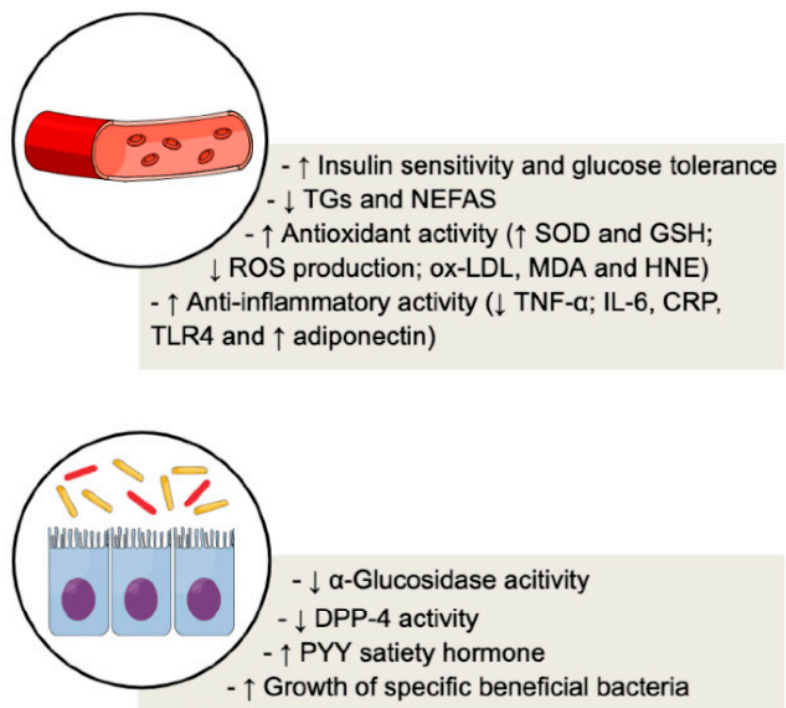

- $\uparrow$ SCFAs production

- $\uparrow$ Mucus layer protection ( $\uparrow$ mucus thickness; MUC-2 gene expression)

- $\uparrow$ Intestinal barrier integrity $(\downarrow$ endotoxemia; $\uparrow$ tight junction protein expression)

- $\uparrow$ Mucosal immunity

Figure 1. BB multi-organ impact within T2DM progression-a multi-modal functional fruit. Preclinical and clinical studies suggest a broad range of systemic and tissue (e.g., pancreas, liver and gut) beneficial mechanisms, which reinforces BB as an attractive nutraceutical to counteract the progression from prediabetes to overt T2DM. $\uparrow$, increased; $\downarrow$, decreased.

In vivo pre-clinical and clinical studies also hint for T2DM improvements upon BB consumption. Regarding animal models, phenolic compounds from a fermented BBblackberry beverage were able to attenuate fasting blood glucose and the development of obesity in C57BL/6J mice [67]. Vendrame et al. [103] also reported that wild BB consumption significantly decreased plasmatic concentrations of HbA1C, resistin, and RBP4 in the obese Zucker rat model of metabolic syndrome along with the repression of hepatic resistin and RBP4 in the abdominal adipose tissue.

Some clinical trials aimed to analyze the potential anti-diabetic effects have also been explored [31,104] (Table 1). In T2DM male volunteers, a single oral capsule of $0.47 \mathrm{~g}$ standardized bilberry extract ( $36 \% w / w$ anthocyanins), equivalent to $50 \mathrm{~g}$ of fresh bilberries, significantly decreased the area under the curve (AUC) for both glucose and insulin in $18 \%$, with no changes on gut incretin hormones (GIP and GLP-1) nor in glucagon and amylin secreted from the pancreas [104]. Moreover, an intervention study showed that daily consumption of a BB smoothie ( $45 \mathrm{~g}$ of blueberry bioactive, equivalent to $\sim 2$ cups of fresh BB per day) for 6 weeks significantly improved insulin sensitivity in thirty-two obese, insulin resistant adults, despite unchanged fasting serum glucose levels [31]. Nevertheless, recent clinical trials reported inconsistencies on the efficacy of BB in ameliorating glucose profile in both T2DM and insulin resistant subjects $[30,105,106]$. A double-blind, randomized controlled trial (RCT) was carried out to evaluate the effect of BB consumption on cardiometabolic parameters in type 2 diabetic men [105]. Twenty-six participants consuming a beverage made from $22 \mathrm{~g}$ of freeze-dried $\mathrm{BB}$ (equivalent to 1 cup of fresh $\mathrm{BB}$ ) daily for 8 weeks had lower HbA1c and fructosamine levels (two biomarkers of glycemic control) 
along with lower triglyceridaemia when compared to participants consuming the placebo. However, no significant changes in total body weight, blood pressure, lipid profile (total cholesterol, LDL and HDL-cholesterol) as well as in serum fasting glucose/insulin concentrations were detected. All of these participants were taking noninsulin diabetes medication and had a good glycemic control [105]. In another study based on a long-term RCT, thirtyseven adults with metabolic syndrome received for 6 months a single-serve sachets with $26 \mathrm{~g}$ of freeze-dried BB (1 cup of BB, equivalent to $150 \mathrm{~g}$ of fresh $\mathrm{BB}$ ) daily. Improved markers of vascular function and elements of lipid status (increased HDL-cholesterol and alipoprotein A-I) were detected following 1 cup of blueberries daily for 6 months. However, no benefits were observed on insulin resistance and sensitivity, measured by HOMA-IR, quantitative insulin sensitivity index (QUICKI) and HbA1c and by the gold standard 2 -step, hyperinsulinemic euglyceminc clamp [107]. This ambiguity between human intervention studies may be due to the heterogeneity of study population, the duration of the study and/or with the specific analytical technique used to assess the glycemic control. In addition, variations in sources and doses of BB-derived phytochemicals, distinct food or beverage matrix or processing may be contributing to the inconsistent findings when assessing the effects on metabolic outcomes.

Table 1. Blueberries effects on biomarkers relevant to T2DM and associated metabolic disorders—clinical evidence.

\begin{tabular}{|c|c|c|c|c|}
\hline Subjects & Source/Dose & Duration & Main Metabolic Outcome & Ref \\
\hline $\begin{array}{l}\text { Participants with } \\
\text { metabolic syndrome }\end{array}$ & $\begin{array}{l}\text { Freeze-dried BB }(26 \mathrm{~g} \text { of } \\
\text { powder, equivalent to } \\
150 \mathrm{~g} \text { of fresh } \mathrm{BB})\end{array}$ & 6 months & $\begin{array}{c}=\text { Insulin Resistance } \\
=\text { HOMA-IR, HbA1c and QUICKI } \\
=\text { Blood pressure } \\
\uparrow \text { HDL and apoA-1 } \\
\uparrow \text { Vascular functions } \\
\downarrow \text { Systemic arterial stiffness } \\
\uparrow \text { Artery endothelial function }\end{array}$ & [107] \\
\hline $\begin{array}{l}\text { Obese subjects with } \\
\text { metabolic syndrome } \\
\quad \text { (pilot study) }\end{array}$ & Meals enriched with BB & $2-4 \mathrm{~h}$ & 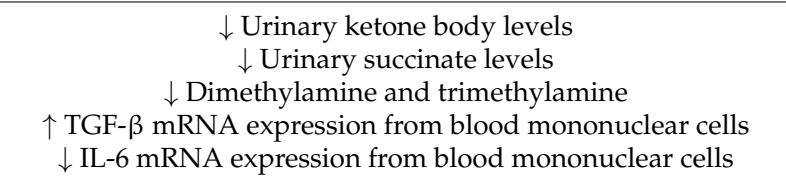 & [108] \\
\hline $\begin{array}{l}\text { Obese nondiabetic and } \\
\text { insulin resistant subjects }\end{array}$ & $\begin{array}{l}\text { Freeze-dried BB (total } 45 \\
\text { g powder; } \approx 2 \text { cups of } \\
\quad \text { fresh } \mathrm{BB})\end{array}$ & 6 weeks & $\begin{array}{c}\uparrow \text { Insulin sensitivity } \\
\downarrow \text { Superoxide and total ROS in whole blood and monocytes } \\
\downarrow \text { Monocytes mRNA expression of TNF- } \alpha \text {, TLR4 and IL-6 }\end{array}$ & [109] \\
\hline $\begin{array}{l}\text { Subjects with metabolic } \\
\text { syndrome }\end{array}$ & $\begin{array}{l}\text { Freeze-dried } \mathrm{BB} \\
\text { beverage }(50 \mathrm{~g}, \approx 350 \mathrm{~g} \\
\text { fresh } \mathrm{BB})\end{array}$ & 8 weeks & 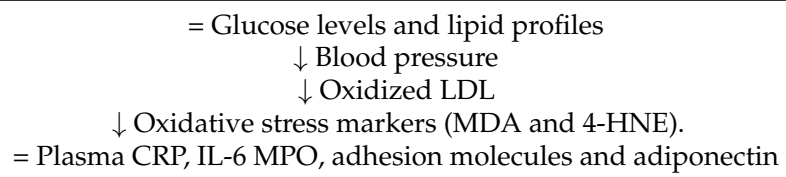 & [110] \\
\hline T2DM patients & $\begin{array}{l}\text { Purified anthocyanins } \\
\text { (320 mg/day } \approx 100 \mathrm{gr} \\
\text { fresh BB } \\
\text { and blackcurrants) }\end{array}$ & 24 weeks & $\begin{array}{c}\downarrow \text { LDL-c, TGs, apo-B and apoC-III } \\
\uparrow \text { HDL } \\
\downarrow \text { Fasting glucose and HOMA-IR } \\
\uparrow \text { Adiponectin and } \beta \text {-hydroxybutyrate } \\
\downarrow \text { Serum IL-6 and TNF- } \alpha \\
\uparrow \text { Antioxidant capacity }\end{array}$ & [111] \\
\hline $\begin{array}{l}\text { Subjects with metabolic } \\
\text { syndrome }\end{array}$ & $\begin{array}{l}\text { Lyophilized BB extract } \\
\text { (BlueKing }{ }^{\circledR}, 2 \text { chewable } \\
\text { tablets/day } 1200 \mathrm{mg} \\
\quad \text { of anthocyanins) }\end{array}$ & 6 months & $\begin{array}{c}=\text { Glucose and insulin levels } \\
=\text { T-Chol and TGs contents } \\
\downarrow \text { DNA damage } \\
\downarrow \text { Vascular endothelium and } \\
\text { cell membranes damage } \\
\downarrow \text { Urinary biomarkers of oxidative stress } \\
(8(\mathrm{OH}) \mathrm{dG} \text { and F2-isoprostanes }) \\
\downarrow \text { Urinary uric acid } \\
\downarrow \text { hs-CRP }\end{array}$ & {$[112]$} \\
\hline
\end{tabular}


Table 1. Cont.

\begin{tabular}{|c|c|c|c|c|}
\hline Subjects & Source/Dose & Duration & Main Metabolic Outcome & Ref \\
\hline T2DM subjects & $\begin{array}{l}\text { Single capsule of } \\
\text { Mirtoselect } \\
{ }^{\circledR} \\
\text { standardized BB extract } \\
(0.47 \mathrm{~g}, 36 \% \\
\text { anthocyanins; } 50 \mathrm{~g} \text { of } \\
\text { fresh BB }\end{array}$ & $\begin{array}{l}1 \text { day and } \\
\text { 2-week } \\
\text { washout } \\
\text { period }\end{array}$ & $\begin{array}{c}\downarrow \text { AUC of GTT } \\
\downarrow \text { Postprandial glucose levels } \\
\downarrow \text { Plasma insulin levels } \\
=\text { Plasma GIP, GLP-1, glucagon and amylin } \\
=\text { Plasma MCP-1 inflammatory adipokine and oxidative } \\
\text { stress markers }\end{array}$ & [104] \\
\hline Men with T2DM & $\begin{array}{l}\text { Freeze-dried } B B(22 \mathrm{~g}, \\
\text { equivalent to } \sim 1 \text { cup } \\
\text { fresh per day) }\end{array}$ & 8 weeks & $\begin{array}{c}=\mathrm{BW} \text { and blood pressure } \\
=\text { Fasting plasma glucose and insulin } \\
=\text { LDL-c, HDL and T-Chol } \\
=\text { CRP } \\
\downarrow \text { HbA1c and fructosamine } \\
\downarrow \text { TGs } \\
\downarrow \text { Hepatic enzymes ALT and AST }\end{array}$ & [105] \\
\hline $\begin{array}{l}\text { Overweight and obese } \\
\text { subjects }\end{array}$ & BB (50 g serving) & 12 weeks & $\begin{array}{c}\downarrow \text { BW, body fat and BMI } \\
\downarrow \text { LDL-c, and T-Chol } \\
\downarrow \text { HbA1c, insulin and insulin resistance } \\
\downarrow \\
\downarrow \text { Hepatic enzyme AST }\end{array}$ & [113] \\
\hline Adults at risk for T2DM & $\begin{array}{l}100 \% \text { wild BB juice } \\
\text { (240 mL/day) }\end{array}$ & 7 days & $\begin{array}{c}=\text { TGs, glucose and insulin levels } \\
=\text { Insulin sensitivity, inflammatory markers, adhesion molecules, } \\
\text { oxidative stress, endothelial function, or blood pressure. } \\
\downarrow \text { Systolic blood pressure } \\
\uparrow \text { Serum nitrates and nitrites levels }\end{array}$ & [30] \\
\hline $\begin{array}{l}\text { Obese, nondiabetic, and } \\
\text { insulin-resistant subjects }\end{array}$ & $\begin{array}{l}\text { BB powder ( } 45 \mathrm{~g} \text {, } \\
\text { equivalent to } \sim 2 \text { cups of } \\
\text { fresh } \mathrm{BB})\end{array}$ & 6 weeks & $\begin{array}{c}\text { = BW } \\
\uparrow \text { Insulin sensitivity } \\
=\text { Adiposity, energy intake } \\
=\text { Serum TNF- } \alpha, \mathrm{MCP}-1 \text { and hs-CRP levels }\end{array}$ & [31] \\
\hline $\begin{array}{l}\text { Patients with } \\
\text { non-alcoholic fatty } \\
\text { liver disease }\end{array}$ & $\begin{array}{l}\text { Purified anthocyanin } \\
(320 \mathrm{mg} / \mathrm{d}) \text { derived } \\
\text { from bilberry and } \\
\text { black currant }\end{array}$ & 12 weeks & 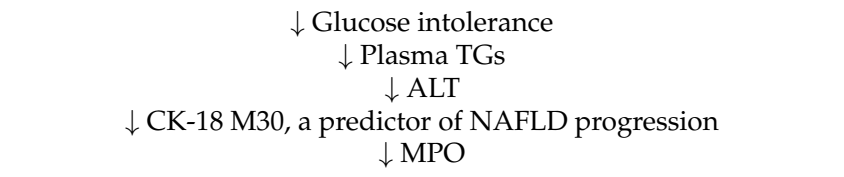 & [114] \\
\hline $\begin{array}{l}\text { Healthy } \\
\text { male individuals }\end{array}$ & $\begin{array}{l}\text { Wild BB powder }(25 \mathrm{~g} \text { in } \\
250 \mathrm{~mL} \text { of water })\end{array}$ & 6 weeks & $\begin{array}{c}\uparrow \text { Bifidobacterium spp. } \\
\uparrow \text { Lactobacillus acidophillus } \\
=\text { Bacteroides spp., Prevotella spp., Enterococcus spp., and } \\
\text { Clostridium coccoides. }\end{array}$ & [115] \\
\hline $\begin{array}{l}\text { Healthy old (aged } \\
65-77 \text { years) women }\end{array}$ & $\begin{array}{l}\text { Freeze-dried BBs } \\
\qquad(38 \mathrm{~g} / \text { day })\end{array}$ & 6 weeks & $\begin{array}{c}\uparrow \alpha \text {-microbiota diversity } \\
\uparrow \text { Healthy microbiota: Faecalibacterium-prauznitzii, B. Intestinihominis, } \\
\text { Ruminococcus bromii, Eubacteriu halli. Anaerostipes hadrus and } \\
\text { Butyrisimonas virosa }\end{array}$ & [116] \\
\hline
\end{tabular}

4-HNE, 4-Hydroxynonenal; 8-OHdG, 8-hydroxy-2'-deoxyguanosine; AUC, area under the curve; CK-18, cytokeratin 18; GIP, gastric inhibitory polypeptide; GTT, glucose tolerance test; HbA1c, glycated hemoglobin; HDL, high-density lipoprotein; hs-CRP, high-sensitivity C-reactive protein; MCP-1, monocyte chemoattractant protein 1; MPO, myeloperoxidase; QUICKI, quantitative insulin sensitivity check index; TGF- $\beta$, transforming growth factor beta; $\uparrow$, increased; $\downarrow$, decreased; $=$, unchanged.

Notably, it is also challenging to identify the optimal dose of polyphenols needed to improve metabolic health since the amount of bioactive compound present in the aforesaid $\mathrm{BB}$ paradigms greatly varies between published studies.

\subsection{Antioxidant and Anti-Inflammatory Properties of BB}

BB owe their antioxidant activities mainly to their phenolic compounds including phenolic acids, condensed tannins and principally, anthocyanins [117,118]. Several studies point to linear correlation between antioxidant activity and the total phenolic concentrations as well as anthocyanins in BB [119-121]. Besides anthocyanins, cinnamic acid derivatives of phenolic acids (e.g., caffeic and chlorogenic acid) were found to be more active antioxidants than benzoic acids derivatives [118].

Chronic hyperglycemia leads to a prooxidant and inflammatory scenario. Conversely, increased oxidative stress and inflammation foster insulin resistance and impaired insulin secretion. Hence, treatments aimed to inhibit ROS overproduction and inflammatory 
markers are welcome to delay the onset and progression of T2DM and related complications [122].

Health beneficial effects of BB phytochemicals are well recognized on the basis of their potent antioxidant and anti-inflammatory properties, particularly in metabolic conditions such as T2DM [96,123,124] (Figure 1). In diabetic human aortic endothelial cells, BB phytochemicals were able to restore cell surface glycosaminoglycan, attenuate endothelial inflammation, suppress monocyte binding and reduce endothelial IL-8 and vascular cell adhesion molecule 1 (VCAM-1) [125]. Additionally, BB anthocyanins extract (BAE) was able to decrease ROS generation while increasing catalase and superoxide dismutase (SOD) activities in high glucose-induced injury of human retinal capillary endothelial cells (HRCECs); furthermore, BAE was also found to influence angiogenesis by decreasing vascular endothelial growth factor (VEGF), intercellular adhesion molecule-1 (ICAM-1) and Akt pathways inhibition [123].

Several in vivo studies highlighted the antioxidant and anti-inflammatory effects of $\mathrm{BB}$ and its specific compounds on metabolic impairments. An overall improvement in the inflammatory status was reported in obese Zucker rats supplemented with wild BB powder [126]. The consumption of $8 \%$ wild blueberry- enriched diet for 8 weeks significantly decreased plasma levels of TNF- $\alpha$, IL- 6 and CRP and increased adiponectin. In addition, the expression of CRP was reduced in the liver, while TNF- $\alpha$, IL- 6 and NF- $\mathrm{KB}$ were down-regulated in both liver and abdominal adipose tissue [126]. In male Wistar rats, BB supplementation in the diet elicited the normalization of TNF- $\alpha$ and IL- $1 \beta$ levels, which were increased by $300 \%$ and $500 \%$ due to a high-fat feeding paradigm [127]. Other authors found that BB powder afforded protection against inflammation of adipose tissue by preventing the upregulation of inflammatory genes (i.e., TNF- $\alpha$ and IL-10) and attenuating oxidative stress (with an increased glutathione peroxidase gene expression), collectively ameliorating obesity-induced insulin resistance [128]. In addition, obese Zucker rats treated during 15 weeks with $\mathrm{BB}$ showed improved glucose tolerance and renal function, together with amelioration of oxidative balance (upholding SOD/catalase antioxidant levels while attenuating oxygen and nitrogen free radical production) and inflammatory pathways (decreased gene and protein expression of TLR4, phosphorylation of ERK and p38-MAPK, NF-kB activity) [129]. Moreover, other studies showed an antioxidant effect of bilberry leaves extract in serum of male Wistar rats under a double challenge composed of HFD and STZ [93]. Likewise, in a recent study from our group, long-term supplementation of BB juice boosted serum antioxidant activity in a healthy Wistar rats [130]. Nevertheless, there has been some controversy on BB-derived polyphenols benefits on total antioxidant activity in both in vivo and human studies [131-135]. Distinct BB doses, food matrices and/or alternative methodologies to assess total antioxidant status may foster such ambiguity.

In humans, previous studies indicated that BB can have immunomodulatory effects and reduce oxidative stress in adults with metabolic syndrome [109]. However, the results so far are relatively inconclusive, possibly due to considerable inter-individual variation. In a 8-week RCT, Basu et al. found that circulating levels of oxidized LDL, MDA and hydroxynonenal (HNE) decreased in participants with metabolic syndrome that consumed $50 \mathrm{~g}$ of freeze-dried BB beverage (approximately $350 \mathrm{~g}$ fresh BB) daily, despite no significant changes in serum glucose levels, lipid profiles or inflammation biomarkers [110]. In another RCT designed to evaluate the effects of 6-weeks intake of $45 \mathrm{~g}$ of freeze-dried BB per day in subjects with metabolic syndrome, a significant decrease in superoxide and total ROS contents were found in whole blood and monocytes, together with decreased circulatory inflammatory markers and reduced gene expression of TNF $\alpha$, TLR4 and IL-6 in monocytes [109]. Similarly, other researchers have found that BB reduced inflammatory markers as well as enhanced antioxidant activity in individuals with metabolic syndrome or diabetes $[109,111]$. 


\subsection{Hepatoprotective Effects of $B B$}

Apart from high antioxidant and anti-inflammatory properties, BB may exert antidiabetic effects by additional mechanisms. It has been unveiled that $B B$ phytochemicals can provide beneficial effects in T2DM by interfering with energy homeostasis and nutrient metabolism in different tissues, including in the liver $[107,136]$.

Several phytochemicals abundant in BB, such as anthocyanins, have been shown to display lipid-lowering actions through hepatic metabolism pathways, including the regulation of key hepatic enzymes involved in lipogenesis and fatty acid catabolism [66,137], as well as in carbohydrate metabolism [94]. A previous in vitro study suggested that concentrate anthocyanins and other polyphenols from BB may improve glucose metabolism by repressing glucose production in H4IIE rat hepatocytes [24]. Additionally, two BB methanolic extracts showed hypoglycemic effects in human non-tumor hepatic $\mathrm{LO} 2$ cells, an effect correlated with the increase in GLUT-2 and PPAR- $\gamma$ expression as well as with the inhibition of relevant inflammatory pathways [59].

The hepatoprotective effects of the BB phytochemicals have been highlighted in several animal models of chemical-induced liver injury $[36,138,139]$ but also in obesity and diabetes-associated chronic diseases, including in NAFLD [36,136,140-142], as summarized in Table 2. A recent study showed that nonacylated anthocyanins from bilberry reduced plasma glucose, lipids and BCAA level in obese diabetic ZDF rats, suggesting an improvement of insulin sensitivity and reduction in lipogenesis [143]. In another study in diabetic mice, antidiabetic effects of dietary anthocyanin-rich bilberry extract (BBE) were associated with targeting of hepatic AMPK, GLUT-4 and metabolic enzymes; furthermore, BBE downregulated the mRNA expression of two gluconeogenic enzymes, phoshoenolpyruvate carboxykinase (PEPCK) and glucose-6-phosphatase (G6Pase), and suppressed glucose flux into the blood [136]. In addition, an enhanced phosphorylation of acetyl-CoA carboxylase (ACC), the key enzyme for FA synthesis that is downstream of AMPK, and the upregulation of PPAR- $\alpha$, acyl-CoA oxidase (ACO) and CPT1, were found in the liver of diabetic mice supplemented with BBE. Furthermore, supplementation of BB polyphenols extracts also decreased the hepatic mRNA expression of SREBP-1 and fatty acid synthase (FAS), which could contribute to improved hepatic lipid metabolism [126]. Other recent findings suggest that phenolic BB extract improved hepatic lipid metabolism via pathways involving the bile acids receptors farnesoid X receptor (FXR) and Takeda G protein-coupled receptor 5 (TGR5) [33].

Moreover, BB phytochemicals elicit mitochondrial-targeted protective properties by scavenging ROS and acting as uncouplers of the OXPHOS, preserving mitochondrial function and protecting cells from apoptosis [144-148] (Figure 1). Likewise, a protective effect of $\mathrm{BB}$ anthocyanin-rich extract was found in mice hepatic mitochondria against acrylamide-induced mitochondrial oxidative stress by inhibition of ROS formation [148]. At the cellular level, C3G (one of the main components of BAE) reduced ROS formation, caspase- 3 and -9 inactivation, and downregulated the pro-apoptotic Bax protein induced by hyperglycemia, preventing mitochondrial dysfunction through modulation of PI3K/AKT and JNK signaling pathways [145]. The combination of BB juice and probiotics (BJP) reduced NAFLD-induced mitochondrial ultrastructure damage and swelling and hepatic necrosis in parallel with improvements on respiratory function. Moreover, BJP attenuated mitochondrial oxidative stress through elevation of GSH and SOD levels while reducing ROS production in an animal model of NAFLD. The authors demonstrated that the modulation of SIRT1/PGC-1 $\alpha$ pathway is a potential target of BJP against hepatic damage induced by NAFLD [146]. More recently, the activation of the AMPK/PGC-1 $\alpha /$ SIRT3 signaling pathway was associated with beneficial effects of BB leaf polyphenols on hepatic mitochondrial function and oxidative defense [140]. Additionally, improvements on mitochondrial respiratory parameters were found in isolated hepatic mitochondria from non-obese diabetic Goto-Kakizaki (GK) rats after drinking bilberry leaves decoction for 4 weeks [149]. Even though a mechanistic explanation was not scrutinized in this study, quercetin present in bilberry leaves may partially explain the increased mitochondrial 
oxidative and phosphorylative activities in GK treated rats. In fact, this polyphenol has a positive impact on mitochondrial biogenesis related with an increased mRNA expression of PGC-1 $\alpha$ and SIRT1 along with higher contents of mtDNA and cytochrome c [150]. Remarkably, recent data from our group revealed that long-term BB fruits intake in a juice form elicited an accentuated bioenergetic remodeling in isolated hepatic mitochondria along with a metabolic transcriptional adaptive response in healthy animals [130]. Further animal research also showed that the attenuation of hepatic steatosis and enhancement of lipolysis following exposure of hepatic cells to BB polyphenols can be promoted by modulation of autophagy [36].

In vivo animal studies have showed that $\mathrm{BB}$ reduced the aspartate aminotransferase (AST) and alanine aminotransferase (ALT) levels in both mouse models of liver injury but also in obese and insulin resistant animal models [32,151]. Conversely, despite changes in lipid peroxidation in the liver, the hepatic TGs accumulation and serum AST and ALT levels were not altered following the administration of whole blueberry powder or polyphenolicrich extracts in diet-induced obesity and insulin resistant mice [152]. Interestingly, authors found that the improved metabolic outcomes were only exhibited in obese insulin resistant animals supplemented with BB polyphenol-rich fractions and no improvements were found in mice fed high-fat high-sucrose diet plus whole BB powder, suggesting that the metabolic benefits are a result of specific classes of polyphenols isolated from the whole fruit.

In humans, some interventional studies have demonstrated the ability of BB to lower hepatic transaminases (such as ALT and AST), which might suggest hepatoprotection $[105,113]$. Moreover, a double-blind RCT conducted in patients with NAFLD for 12 weeks demonstrated beneficial effects of purified anthocyanins derived from bilberry and black currant by improving insulin resistance [114].

Table 2. Blueberries hepatoprotective effects in (pre)diabetic animal models.

\begin{tabular}{|c|c|c|c|c|}
\hline Animal Model & Source/Dose & Duration & Main Outcomes & Ref \\
\hline $\begin{array}{l}\text { HFD-fed male } \\
\text { C57BL/6J mice }\end{array}$ & $\begin{array}{l}\text { BB anthocyanin } \\
\text { extract }(200 \mathrm{mg} / \mathrm{kg} \mathrm{BW})\end{array}$ & 8 weeks & $\begin{array}{c}\downarrow \text { BW, liver and adipose tissue weight } \\
\downarrow \text { Insulin levels } \\
\downarrow \text { HOMA-IR } \\
\downarrow \text { TGs and T-Chol } \\
\downarrow \text { Hepatic steatosis } \\
\downarrow \text { Serum ceramide and DAG levels } \\
\downarrow \text { Serum PP2A and Prkcz mRNA expression } \\
\downarrow \text { ALT and AST activities }\end{array}$ & [32] \\
\hline \multirow{2}{*}{ Obese Zucker rats } & \multirow{2}{*}{$\begin{array}{l}\text { Freeze-dried wild BB } \\
\text { powder ( } 8 \% \text { of diet) }\end{array}$} & \multirow{2}{*}{8 weeks } & $\begin{array}{c}=\text { BW } \\
\downarrow \text { Fasting plasma TAG and T-Chol } \\
\downarrow \text { Hepatic SREBP- } 1 \text { and FAS mRNA expression } \\
=\text { Hepatic PPAR- } \alpha \text { and PPAR- } \gamma \text { mRNA expression }\end{array}$ & [126] \\
\hline & & & $\begin{array}{c}\downarrow \text { Fasting plasma TNF- } \alpha, \text { IL-6, and CRP } \\
\text { } \text { Plasma adiponectin } \\
\downarrow \text { Hepatic TNF- } \alpha, \text { IL-6, CRP and NF-kB mRNA expression }\end{array}$ & [153] \\
\hline \multirow[b]{2}{*}{$\begin{array}{l}\text { HFD-fed Sprague } \\
\text { Dawley rat }\end{array}$} & \multirow{2}{*}{$\begin{array}{c}\text { BB juice }(15 \mathrm{~g} / \mathrm{kg}) \\
\text { combined } \\
\text { with probiotics }\end{array}$} & \multirow[b]{2}{*}{8 weeks } & $\begin{array}{c}\downarrow \text { Serum TGs, T-Chol, LDL-c and MDA } \\
\downarrow \text { Hepatic lipid accumulation } \\
\uparrow \text { Hepatic SIRT1and PPAR- } \alpha \text { mRNA and protein expression } \\
\downarrow \text { Hepatic mRNA levels of SREBP-1c } \\
\uparrow \text { Serum SOD and GSH activities } \\
\downarrow \downarrow \text { Serum ALT and AST activities }\end{array}$ & [151] \\
\hline & & & $\begin{array}{c}\uparrow \text { Hepatic mitochondrial swelling } \\
\downarrow \text { State } 3 \text { and } 4 \text { respiration rates } \\
\uparrow \text { RCR and ADP /O ratio } \\
\text { expression levels } \\
\uparrow \text { Hepatic mitochondrial GSH and SOD mRNA and protein } \\
\uparrow \text { Hepatic protein and mRNA expression of SIRT1 } \\
\uparrow \text { Hepatic mRNA expression of PGC- } 1 \alpha \\
\downarrow \text { Hepatic mitochondrial MDA levels and ROS activity }\end{array}$ & [146] \\
\hline
\end{tabular}


Table 2. Cont

\begin{tabular}{|c|c|c|c|c|}
\hline Animal Model & Source/Dose & Duration & Main Outcomes & Ref \\
\hline $\begin{array}{c}\text { HFD-fed obese } \\
\text { postmenopausal female } \\
\text { C57BL/6J mice }\end{array}$ & BB powder (4\% of diet) & 12 weeks & $\begin{array}{c}=\text { BW and fat mass } \\
\uparrow \text { Glucose tolerance } \\
\downarrow \text { Hepatic steatosis } \\
\uparrow \text { Hepatic FAO and lipid handling ( } \uparrow \text { LCHAD, and FAT /CD36 } \\
\text { mRNA expression) } \\
\uparrow \text { Fecal SCFAs levels }\end{array}$ & [154] \\
\hline HFD-fed C57BL/6J mice & $\begin{array}{c}\text { BB polyphenol } \\
\text { extract } \\
\text { (200 mg/kg body } \\
\text { weight (bw)/day) }\end{array}$ & 12 weeks & $\begin{array}{c}\downarrow \text { BW } \\
\downarrow \text { Serum LDL -c levels } \\
\uparrow \text { Serum HDL-c levels } \\
\downarrow \text { Hepatic TGS and T-Chol } \\
\downarrow \text { Hepatic PPAR- } \gamma \text {, FAS, and SREBP-1 mRNA expression } \\
\uparrow \text { Hepatic CPT1 and PPAR- } \alpha \text { mRNA expression } \\
\uparrow \text { AMPK phosphorylation }\end{array}$ & [34] \\
\hline $\begin{array}{l}\text { HFD-fed male } \\
\text { C57BL/6J mice }\end{array}$ & $\begin{array}{l}\text { BB anthocyanins } \\
(200 \mathrm{mg} / \mathrm{kg})\end{array}$ & 12 weeks & $\begin{array}{c}\downarrow \downarrow \text { BW } \\
\downarrow \text { Serum and hepatic lipid and MDA levels } \\
\uparrow \text { Hepatic SOD and GPx activities } \\
\downarrow \text { TNF- } \alpha, \text { IL-6 and NF-kB mRNA expression } \\
\uparrow \text { Fecal SCFAS } \\
\text { Hepatic glycerophospholipids and glutathione metabolism and } \\
\text { insulin-signaling pathways modulation }\end{array}$ & [155] \\
\hline $\begin{array}{l}\text { Diabetic male } \\
\text { KK-Ay mice }\end{array}$ & $\begin{array}{c}\text { BB anthocyanin extract } \\
(10 \mathrm{~g} / \mathrm{Kg} \text { diet })\end{array}$ & 4 weeks & $\begin{array}{c}=\text { BW and } \downarrow \text { liver weight } \\
\downarrow \text { Serum glucose levels } \\
\uparrow \text { Insulin sensitivity } \\
\downarrow \text { Serum TGs and TC-Chol } \\
\downarrow \text { HGP } \\
\uparrow \text { Hepatic AMPK phosphorylation } \\
\downarrow \text { Hepatic lipid content } \\
\downarrow \text { Hepatic gluconeogenesis ( } \downarrow \text { PEPCK and G6Pase mRNA } \\
\text { expression) } \\
\uparrow \text { FAO ( } \uparrow \text { PPAR- } \alpha, \text { ACO and CPT1 mRNA expression) }\end{array}$ & [136] \\
\hline HFD-fed C57BL/6J mice & Fermented BB juice & 17 weeks & $\begin{array}{c}\uparrow \text { BW gain } \\
\uparrow \text { Insulin sensitivity and glucose homeostasis } \\
\downarrow \text { Fasting serum glucose } \\
\downarrow \text { Serum LDL-c } \\
\downarrow \text { Serum TNF- } \alpha \text { and } \uparrow \text { IL-10 } \\
\downarrow \text { Hepatic fat accumulation } \\
\uparrow \text { Hepatic mRNA expression of IR and IRS } \\
\downarrow \text { Hepatic SCD1, SREBP1c and FAS expression } \\
\uparrow \text { mRNA and protein expression of GLUT-1; GCK, LDL-receptor } \\
\quad \text { and PPAR- } \alpha \\
\downarrow \text { mRNA and protein expression of PPAR- } \gamma \\
\uparrow \text { Akt phosphorylation }\end{array}$ & [156] \\
\hline GK rats & $\begin{array}{c}\text { Decoctions of Vaccinium } \\
\text { myrtillus L. } \\
\text { (bilberry) leaves }\end{array}$ & 4 weeks & $\begin{array}{c}\text { = BW } \\
\uparrow \text { Glucose tolerance } \\
\downarrow \text { Occasional glycaemia } \\
\uparrow \text { Mitochondrial oxidative and phosphorylative activities } \\
\uparrow \text { State } 3 \text { respiration, FCCP-uncoupled respiratory and RCR } \\
\text { activities }\end{array}$ & [149] \\
\hline
\end{tabular}

ACO, acyl-CoA oxidase; Akt, protein kinase B; ALT, alanine aminotransferase; AMPK, $5^{\prime}$ adenosine monophosphate-activated protein kinase; AST, aspartate aminotransferase; BW, body weight; CPT1, carnitinepalmitoyltransferase-1A; DAG, diacylglycerol; FAO, fatty acid oxidation; FAS, fatty acid synthase; FCCP, carbonyl cyanide p-(tri-fluromethoxy)phenyl-hydrazone; G6Pase, glucose 6-phosphatase; GCK, Glucokinase; GLUT-1, glucose transporter 1; GPx, glutathione peroxidase; GK, Goto-Kakizaki; HGP, hepatic glucose production; HFD, high-fat diet; HOMA-IR, homeostatic model assessment for insulin resistance; IL, interleukin; LCHAD, long-chain hydroxyacyl-CoA dehydrogenase; LDL-c, low-density lipoprotein-cholesterol; MDA, malondialdehyde; PEPCK, phosphoenolpyruvate carboxykinase; RCR, respiratory control ratio; SCD1, stearoyl-CoA desaturase-1; SCFAS, short-chain fatty acids; SOD, superoxide dismutase; SREBP-1, sterol regulatory element-binding protein-1; TNF- $\alpha$, tumor necrosis factor- $\alpha$; T-Chol, total-cholesterol; $\uparrow$, increased; $\downarrow$, decreased; $=$, unchanged.

\subsection{Prebiotic-like Effects of $B B$}

Given that BB phytochemical composition comprises several bioactive compounds including high molecular weight PP and easily fermentable dietary fibers that are not well absorbed in the small intestine and reach the large intestine, such bioactive components are available to interact with GM [157]. Indeed, prebiotic-like properties and/or antimicrobial effects against pathogenic intestinal bacteria of $\mathrm{BB}$ and their bioactive compounds 
have been reported in in vitro assays $[116,158,159]$, in animal models $[152,160]$ and in human intervention studies $[115,161]$, as outlined in Figure 1. An in vitro study reported distinct positive correlations between different PP contents and bacterial species; in fact, while PP from BB bagasse powder was correlated with Actinobacteria (Bifidobacterium and Collisella) and Akkermansia, the fiber content was associated with Faecalibacterium and Bifidobacterium [159]. Moreover, the presence of anthocyanins and fibers in BB pomace promoted the growth of Lactobacillus and Ruminococcaceae genus and was negatively associated with Streptococcus. The addition of a BB extract to mixed human fecal bacterial populations enhanced the population size of Lactobacilli and Bifidobacteria [160].

Growing evidence hint that the positive effects of BB in improving glucose metabolism and energy balance are closely linked with their ability to modulate the composition and/or function of GM [34,152,157,162]. Table 3 summarizes the most relevant studies performed in animal models. A recent study reported that upon intestinal absorption BB polyphenols improved metabolic health in diet-induced obese mice via modulation of GM rather than through systemic effects [152]. It was also observed that germ-free mice receiving fecal microbiota transplantation (FMT) from mice fed BB polyphenolic fractions (specifically enriched with proanthocyanins or anthocyanidins) were protected from diet-induced obesity and presented an improved insulin sensitivity and glucose homeostasis when compared to mice receiving GM from HFHS fed mice. Furthermore, authors postulated that the beneficial effects of FMT could be the result of a decreased proportion of BCAA in the feces of mice fed whole BB or just the polyphenols [152]. Moreover, positive effects on insulin sensitivity and glycemia were found in the mouse model of HFD-induced obesity upon BB juice supplementation for 17 weeks, with or without fermentation [156]; the authors hypothesized that this protection was closely related with BB ability to stimulate SCFAs production and maintain GM homeostasis [156].

Table 3. Blueberries gut modulatory and prebiotic effects in T2DM or metabolic syndrome animal models.

\begin{tabular}{|c|c|c|c|c|}
\hline Animal Model & Source/Dose & Duration & Main Outcomes & Ref \\
\hline HFD-fed C57BL/6J mice & $\begin{array}{l}\text { BB polyphenol extract } \\
(200 \mathrm{mg} / \mathrm{kg})\end{array}$ & 12 weeks & $\begin{array}{c}\downarrow \text { Prevotella and Clostridium } \\
\downarrow \text { Lactobacillus spp. and Coprobacillus } \\
\uparrow \text { Proteobacteria and Helicobacter } \\
\uparrow \text { Bifidobacterium }\end{array}$ & [34] \\
\hline \multirow[t]{2}{*}{$\begin{array}{l}\text { HFHS diet-fed male } \\
\text { C57BL/6J mice }\end{array}$} & $\begin{array}{l}\text { BB polyphenol extract } \\
(200 \mathrm{mg} / \mathrm{kg})\end{array}$ & 8 weeks & $\begin{array}{c}\uparrow \text { Glucose tolerance } \\
\uparrow \text { Colonic mucus thickness } \\
\uparrow \text { Ruminococcaceae and Peptostreptococcaceae } \\
\downarrow \text { Bacteroidetes phylum } \\
=\text { Akkermansia muciniphila } \\
\uparrow \text { Adlercreutzia equolifaciens }\end{array}$ & \multirow[t]{2}{*}{ [162] } \\
\hline & $\begin{array}{c}\text { BB oligomeric } \\
\text { proanthocyanidins } \\
\text { fraction }(53 \mathrm{mg} / \mathrm{kg})\end{array}$ & 8 weeks & $\begin{array}{c}\uparrow \text { Glucose tolerance } \\
\uparrow \text { Colonic mucus thickness } \\
\uparrow \text { Akkermansia muciniphila } \\
\uparrow \text { Adlercreutzia equolifaciens } \\
\downarrow \text { Ruminococcaceae and Peptostreptococcaceae }\end{array}$ & \\
\hline $\begin{array}{l}\text { HFD-fed male C57BL/6J } \\
\text { mice and diabetic male } \\
\text { C57BL/KsJ db/db mice }\end{array}$ & $\begin{array}{l}\text { BB phenolic extract (5 } \\
\mathrm{g} / \mathrm{L} \text { in drinking water) }\end{array}$ & 14 weeks & $\begin{array}{c}\downarrow \text { BW gain and adiposity } \\
\uparrow \text { Glucose tolerance and insulin sensitivity } \\
\downarrow \text { Plasma LPS, IL-6, TNF- } \alpha \text { contents } \\
\downarrow \text { Hepatic steatosis } \\
\downarrow \text { Plasmatic and hepatic TGs } \\
\downarrow \text { Serum LDH, ALT and AST } \\
\uparrow \text { Intestinal MUC-2 levels } \\
\downarrow \text { Intestinal occludin and ZO-1 mRNA expression } \\
\downarrow \text { Intestinal and hepatic inflammation (TLR4, IL-6, TNF- } \alpha \text { ) } \\
\uparrow \text { Bifidobacteria and Akkermansia } \\
\downarrow \text { Desulfovibrio and Bilophila genera } \\
\downarrow \text { Plasma BA pool size } \\
\downarrow \text { mRNA expression levels of SREBP-1c and ChREBP and } \\
\text { downstream genes }\end{array}$ & [33] \\
\hline
\end{tabular}


Table 3. Cont

\begin{tabular}{|c|c|c|c|c|}
\hline Animal Model & Source/Dose & Duration & Main Outcomes & Ref \\
\hline $\begin{array}{l}\text { HFD-fed male Sprague } \\
\text { Dawley rats }\end{array}$ & $\begin{array}{l}\text { Dietary fiber from BB } \\
\text { (7\% of diet) }\end{array}$ & 8 weeks & $\begin{array}{c}\downarrow \text { BW gain } \\
\downarrow \text { Serum T-Chol levels } \\
\downarrow \text { Hepatic steratosis } \\
\downarrow \text { Hepatic mRNA expression of SCD1 } \\
=\text { Hepatic mRNA expression of genes involved in lipogenesis and } \\
\beta \text {-oxidation } \\
\uparrow \text { mRNA expression of Ucp-1 } \\
\uparrow \text { Fecal and serum total SCFAs } \\
\uparrow \text { Butyrate-producing bacteria } \\
\uparrow \text { Actinobacteria and Proteobacteria } \\
\downarrow \text { Firmicutes and } \uparrow \text { Bacteroidetes } \\
=\text { Bifidobacterium }\end{array}$ & [163] \\
\hline \multirow[b]{2}{*}{$\begin{array}{l}\text { HFHS diet-fed male } \\
\text { C57BL/6 mice }\end{array}$} & $\begin{array}{c}\text { Freeze dried BB powder } \\
(4 \% \text { of diet, } \\
160 \mathrm{mg} / \text { day })\end{array}$ & 12 weeks & $\begin{array}{c}\quad=\text { BW and liver weight } \\
\quad=\text { HOMA-IR } \\
=\text { Glucose homeostasis } \\
=\text { Hepatic TGs, T-Chol } \\
=\text { Plasma ALT and AST } \\
\downarrow \text { Fecal BCFA isobutyric and isovaleric acid } \\
\downarrow \text { Ruminococcus, Lachnospiraceae and Blautia }\end{array}$ & \multirow[b]{2}{*}{152} \\
\hline & $\begin{array}{l}\text { BB proanthocyanidin } \\
\text { extract }(1 \mathrm{mg} / \text { day })\end{array}$ & 12 weeks & $\begin{array}{c}\downarrow \text { BW and epididymal adipose tissue weight } \\
\downarrow \text { Plasma insulin and C-peptide levels } \\
\downarrow \text { HOMA-IR } \\
\uparrow \text { Insulin sensitivity } \\
=\text { Hepatic TGs, T-Chol } \\
=\text { Plasma ALT and AST } \\
\downarrow \text { BCFA isobutyric and isovaleric acid } \\
\uparrow \text { Muribaculum inestinale abundance } \\
\uparrow \text { Oxidative phosphorylation pathway } \\
\uparrow \text { Homeostasis and insulin sensitivity after transferred by FMT }\end{array}$ & \\
\hline HFD-fed Wistar rats & $\begin{array}{l}\text { Freeze-dried BB powder } \\
\quad(10 \% \text { of diet }\end{array}$ & 8 weeks & $\begin{array}{c}=\text { BW } \\
\uparrow \text { Insulin sensitivity } \\
\downarrow \text { Serum LBP levels } \\
\downarrow \text { Hepatic p-IRS1 to IRS1 ratio } \\
\downarrow \text { Hepatic MDA concentration } \\
\uparrow \text { Ileal mRNA expression of Muc-2 } \\
\downarrow \text { Ileal mRNA expression of TNF- } \alpha \\
\uparrow \text { Goblet cell number per crypt } \\
\uparrow \text { Gammaproteobacteria (Actinobacillus and Aggregatibacter) } \\
\uparrow \text { Lactobaccilus } \\
\downarrow \text { Firmicutes and Bacteroidetes } \\
\uparrow \text { Serum SCFAs (acetate and propionate) } \\
\uparrow \text { Ileal mRNA expression of GLP-1 }\end{array}$ & [127] \\
\hline HFD-fed C57BL/6J mice & $\begin{array}{l}\text { Fermented BB juice and } \\
\text { fresh BB juice }\end{array}$ & 17 weeks & $\begin{array}{c}\uparrow \text { Cecum SCFAs (acetate and valerate) } \\
\uparrow \text { Bacteroidetes (Barnesiella) } \\
\downarrow \text { Firmicutes } \\
\uparrow \text { Akkermansia, Bifidobacterium, and Lactobacillus } \\
\downarrow \text { Obese-type gut microbiota (Oscillibacter and Alistipes) }\end{array}$ & [156] \\
\hline
\end{tabular}

BA, bile acids; BCFA, branched chain fatty acids; FMT, fecal microbiota transplant; FXR, farnesoid X receptor; GLP-1, glucagon-like peptide-1; HFD, high-fat diet; HFHS, high-fat high sucrose; IRS-1, insulin receptor substrate-1; LBP, lipopolysaccharide-binding protein; LDH, lactate dehydrogenase; LPS, lipopolysaccharides; Muc-2, mucin 2; SCFAs, short chain fatty acids; TGR5, G-protein-coupled bile acid receptor; TLR4, Toll-like receptor 4; Ucp-1, uncoupling protein-1; ZO-1, zonula occludens-1; $\uparrow$, increased; $\downarrow$, decreased; =, unchanged.

Among health commensal bacteria, Akkermansia muciniphila (AM) has been positively correlated with enhanced mucosal barrier function and improved metabolic phenotype in obesity ad T2DM [116,164-166]. Notably, BB interventions enhanced AM levels in animal models of metabolic syndrome $[162,167]$. Indeed, whilst favouring the growth of healthier bacteria, BB constituents seem to display the ability to restore gastrointestinal integrity by: (i) enhancing colonic mucus thickness [162]; (ii) increasing the expression of tight junctions proteins [168]; (iii) overexpressing MUC-2 mRNA, the primary glycoprotein of the gastrointestinal mucus layer [127]; (iv) reducing endotoxemia and intestinal inflammation [33,127] and (v) fortifying the mucosal immunity [167]. 
Interestingly, BB polymeric proanthocyanidins have been recently shown capacity to restore the colonic mucus layer, modulate GM and attenuate glucose tolerance in obese mice, in contrast to the anthocyanin fraction from BB [162]. However, other subclasses of polyphenols, secondary metabolites and fibers also present in BB may potentially account for these prebiotic effects counteracting the metabolic disorders $[35,116,169]$. Notwithstanding, ambiguous studies and conflicting results still prevail, which could possibly be explained by several factors such as distinct duration and mode of administration of BB interventions, differences in the BB phytochemical composition (i.e., the type and structure of polyphenolic constituents), as well as differences in the dietary regimens. Noteworthy, the inclusion of bilberries in the high-fat setting prompted an increase in SCFA contents accompanied by the normalized $\alpha$-diversity of GM, enhanced the abundance of Bacteroidetes, Bifidobacterium and butyrate-producing bacteria, which collectively contributed to thwart pre-obesity events like hepatic lipid accumulation [163].

The impact of BB on GM has been also evaluated in human interventional studies [161]. Vendrame et al. [115] showed that 6 weeks consumption of a BB powder drink rich in anthocyanins significantly enhanced the abundance of Bifidobacteria in the cecum from healthy volunteers, whereas no differences were observed for Bacteroides spp., Prevotella spp., Enterococcus spp., and Clostridium coccoides. A pilot RCT was carried out in overweight and obese subjects to evaluate the effects of a gastrointestinal microbiome modulator (GIMM), composed of inulin, $\beta$-glucan and anthocyanins and polyphenols from BB, on metabolic parameters, fecal markers of GM, and satiety [170]. Thirty overweight or obese participants consumed the GIMM or placebo, daily, for 4 weeks. Improved glucose tolerance restored satiety hormones (increased PYY and decreased ghrelin) and fecal SCFAs contents were observed in the GIMM-treated group when compared to the placebo; however, no significant changes were found between groups regarding insulin sensitivity, fecal markers of GM, plasma satiety hormones or serum lipid concentrations [170]. The prebiotic effects of BB reported in the preclinical ground need further validation in the clinical setting, namely in the (pre)diabetic state, as the literature is particularly scarce in human interventions in this condition. There is one ongoing clinical trial (NCT03266055) exploring the prebiotic effects of $\mathrm{BB}$ in subjects with metabolic syndrome. The results from this and other trials further conducted will be decisive to achieve more robust conclusions regarding the use of $\mathrm{BB}$ to prevent dysbiosis in prediabetes.

\section{Concludings}

Herein, we provide a review of the current knowledge in this field by revisiting preclinical data obtained from in vitro assays and animal models together with studies from human subjects, to disclose the mechanisms by which BB may be a valuable approach in prediabetes (Figure 1). Through improving glycemic control, reducing oxidative stress and inflammation, regulating TG's accumulation and trafficking, along with ameliorating GM dysbiosis, this multi-modal functional fruit positively impacts a diversity of pathophysiological mechanisms that occur as early as prediabetes and for which pharmacological interventions (either oral antidiabetics or weight-loss drugs) are not approved in practical guidelines [17] or are only considered in cases at high risk [171]. In this sense, BB have been shown to modulate hepatic and intestinal molecular targets of currently approved antidiabetics [ $\alpha$-glucosidase inhibitors (e.g., acarbose), DPP-4 inhibitors (e.g., sitagliptin), PT1B inhibitors (rosiglitazone)] [98,172,173], whose benefits often surpass the glucocentric view of diabetes management $[174,175]$. As a matter of fact, $\mathrm{BB}$ benefits also goes beyond the improvement of glycemic control as they positively modulate a panoply of metabolic functions that ensues not only in the pancreas but also in the gut and the liver, two pathophysiologic paths that critically determine (pre)diabetes progression. Collectively, it is outlined how blueberries may provide a fruitful source of phytochemicals able to prevent (pre)diabetes progression.

As final critical analysis, two serious limitations narrow our current understanding of BB health benefits on (pre)diabetes. Firstly, many in vivo and in vitro studies were con- 
ducted with BB-derived PP in supraphysiological doses, unlikely to be achieved upon human daily consumption. Secondly, most in vitro studies use undigested dietary BB-derived polyphenols and miss the corresponding in vivo metabolites/conjugates. Collectively, these data have a low predictive value. Finally, RCTs greatly diverge on BB supplementation regimens. Future research should focus on the qualitative and quantitative evaluation of BB polyphenols in both systemic circulation and target tissues. Moreover, longer-term RCTs with standardized interventions (e.g., doses employed, duration) and readouts will hopefully bring stronger evidence to guide a more effective use of this functional fruit with remarkable antioxidant activity in the early stage of diabetes.

Author Contributions: Conceptualization, S.N., S.D.V. and F.R.; writing-original draft preparation, S.N., P.V., P.G., S.D.V. and F.R.; writing-review and editing, S.N., S.D.V. and F.R.; supervision, S.D.V. and F.R.; project administration, F.R.; funding acquisition, F.R. All authors have read and agreed to the published version of the manuscript.

Funding: This work was supported by the European Regional Development Fund (FEDER), through Programa Operacional Factores de Competitividade COMPETE2020 (CENTRO-01-0145-FEDER000012-HealthyAging2020) and by National funds via Portuguese Science and Technology Foundation (FCT): Strategic Projects UID/NEU/04539/2013, UID/NEU/04539/2019, UIDB/04539/2020 and UIDP/04539/2020 (CIBB), SFRH/BD/109017/2015 (PhD Fellowship) and PTDC/SAU-NUT/31712/ 2017, as well as by COMPETE-FEDER funds (POCI-01-0145-FEDER-007440 and POCI-01-0145FEDER-031712).

Conflicts of Interest: The authors declare no conflict of interest.

\section{References}

1. Zheng, Y.; Ley, S.H.; Hu, F.B. Global aetiology and epidemiology of type 2 diabetes mellitus and its complications. Nat. Rev. Endocrinol. 2018, 14, 88-98. [CrossRef]

2. Saeedi, P.; Petersohn, I.; Salpea, P.; Malanda, B.; Karuranga, S.; Unwin, N.; Colagiuri, S.; Guariguata, L.; Motala, A.A.; Ogurtsova, K.; et al. Global and regional diabetes prevalence estimates for 2019 and projections for 2030 and 2045: Results from the International Diabetes Federation Diabetes Atlas, 9th edition. Diabetes Res. Clin. Pr. 2019, 157, 107843. [CrossRef]

3. Williams, R.; Karuranga, S.; Malanda, B.; Saeedi, P.; Basit, A.; Besancon, S.; Bommer, C.; Esteghamati, A.; Ogurtsova, K.; Zhang, P.; et al. Global and regional estimates and projections of diabetes-related health expenditure: Results from the International Diabetes Federation Diabetes Atlas, 9th edition. Diabetes Res. Clin. Pr. 2020, 162, 108072. [CrossRef]

4. World Health Organization; International Diabetes Federation. Definition and Diagnosis of Diabetes Mellitus and Intermediate Hyperglycaemia: Report of a WHO/IDF Consultation; WHO: Geneva, Switzerland, 2006.

5. Tabak, A.G.; Herder, C.; Rathmann, W.; Brunner, E.J.; Kivimaki, M. Prediabetes: A high-risk state for diabetes development. Lancet 2012, 379, 2279-2290. [CrossRef]

6. Abdul-Ghani, M.A.; DeFronzo, R.A. Pathophysiology of prediabetes. Curr. Diabetes Rep. 2009, 9, 193-199. [CrossRef] [PubMed]

7. Bansal, N. Prediabetes diagnosis and treatment: A review. World J. Diabetes 2015, 6, 296-303. [CrossRef] [PubMed]

8. Nathan, D.M.; Davidson, M.B.; DeFronzo, R.A.; Heine, R.J.; Henry, R.R.; Pratley, R.; Zinman, B.; American Diabetes, A. Impaired fasting glucose and impaired glucose tolerance: Implications for care. Diabetes Care 2007, 30, 753-759. [CrossRef] [PubMed]

9. Huang, Y.; Cai, X.; Qiu, M.; Chen, P.; Tang, H.; Hu, Y.; Huang, Y. Prediabetes and the risk of cancer: A meta-analysis. Diabetologia 2014, 57, 2261-2269. [CrossRef] [PubMed]

10. Huang, Y.; Cai, X.; Chen, P.; Mai, W.; Tang, H.; Huang, Y.; Hu, Y. Associations of prediabetes with all-cause and cardiovascular mortality: A meta-analysis. Ann. Med. 2014, 46, 684-692. [CrossRef]

11. Tuomilehto, J.; Lindstrom, J.; Eriksson, J.G.; Valle, T.T.; Hamalainen, H.; Ilanne-Parikka, P.; Keinanen-Kiukaanniemi, S.; Laakso, M.; Louheranta, A.; Rastas, M.; et al. Prevention of type 2 diabetes mellitus by changes in lifestyle among subjects with impaired glucose tolerance. N. Engl. J. Med. 2001, 344, 1343-1350. [CrossRef]

12. Wild, S.; Roglic, G.; Green, A.; Sicree, R.; King, H. Global prevalence of diabetes: Estimates for the year 2000 and projections for 2030. Diabetes Care 2004, 27, 1047-1053. [CrossRef]

13. Wu, H.; Tremaroli, V.; Schmidt, C.; Lundqvist, A.; Olsson, L.M.; Kramer, M.; Gummesson, A.; Perkins, R.; Bergstrom, G.; Backhed, F. The Gut Microbiota in Prediabetes and Diabetes: A Population-Based Cross-Sectional Study. Cell Metab. 2020, 32, 379-390.e373. [CrossRef]

14. Zhang, X.; Shen, D.; Fang, Z.; Jie, Z.; Qiu, X.; Zhang, C.; Chen, Y.; Ji, L. Human gut microbiota changes reveal the progression of glucose intolerance. PLOS ONE 2013, 8, e71108. [CrossRef]

15. Daniele, G.; Abdul-Ghani, M.; DeFronzo, R.A. What are the pharmacotherapy options for treating prediabetes? Expert Opin. Pharm. 2014, 15, 2003-2018. [CrossRef] 
16. Feinberg, T.; Wieland, L.S.; Miller, L.E.; Munir, K.; Pollin, T.I.; Shuldiner, A.R.; Amoils, S.; Gallagher, L.; Bahr-Robertson, M.; D'Adamo, C.R. Polyherbal dietary supplementation for prediabetic adults: Study protocol for a randomized controlled trial. Trials 2019, 20, 24. [CrossRef] [PubMed]

17. Garber, A.J.; Abrahamson, M.J.; Barzilay, J.I.; Blonde, L.; Bloomgarden, Z.T.; Bush, M.A.; Dagogo-Jack, S.; DeFronzo, R.A.; Einhorn, D.; Fonseca, V.A.; et al. Consensus Statement by the American Association of Clinical Endocrinologists and American College of Endocrinology on the Comprehensive Type 2 Diabetes Management Algorithm-2018 Executive Summary. Endocr. Pract. 2018, 24, 91-120. [CrossRef] [PubMed]

18. Mechanick, J.I.; Marchetti, A.E.; Apovian, C.; Benchimol, A.K.; Bisschop, P.H.; Bolio-Galvis, A.; Hegazi, R.A.; Jenkins, D.; Mendoza, E.; Sanz, M.L.; et al. Diabetes-specific nutrition algorithm: A transcultural program to optimize diabetes and prediabetes care. Curr. Diabetes Rep. 2012, 12, 180-194. [CrossRef]

19. Li, M.; Fan, Y.; Zhang, X.; Hou, W.; Tang, Z. Fruit and vegetable intake and risk of type 2 diabetes mellitus: Meta-analysis of prospective cohort studies. BMJ Open 2014, 4, e005497. [CrossRef]

20. Muraki, I.; Imamura, F.; Manson, J.E.; Hu, F.B.; Willett, W.C.; van Dam, R.M.; Sun, Q. Fruit consumption and risk of type 2 diabetes: Results from three prospective longitudinal cohort studies. BMJ 2013, 347, f5001. [CrossRef] [PubMed]

21. Wang, P.Y.; Fang, J.C.; Gao, Z.H.; Zhang, C.; Xie, S.Y. Higher intake of fruits, vegetables or their fiber reduces the risk of type 2 diabetes: A meta-analysis. J. Diabetes Investig. 2016, 7, 56-69. [CrossRef]

22. Esfandiar, Z.; Hosseini-Esfahani, F.; Mirmiran, P.; Yuzbashian, E.; Azizi, F. The Association of Dietary Polyphenol Intake with the Risk of Type 2 Diabetes: Tehran Lipid and Glucose Study. Diabetes Metab. Syndr. Obes. 2020, 13, 1643-1652. [CrossRef] [PubMed]

23. Minich, D.M.; Bland, J.S. Dietary management of the metabolic syndrome beyond macronutrients. Nutr. Rev. 2008, 66, 429-444. [CrossRef] [PubMed]

24. Roopchand, D.E.; Kuhn, P.; Rojo, L.E.; Lila, M.A.; Raskin, I. Blueberry polyphenol-enriched soybean flour reduces hyperglycemia, body weight gain and serum cholesterol in mice. Pharm. Res. 2013, 68, 59-67. [CrossRef] [PubMed]

25. Kassaian, N.; Feizi, A.; Aminorroaya, A.; Jafari, P.; Ebrahimi, M.T.; Amini, M. The effects of probiotics and synbiotic supplementation on glucose and insulin metabolism in adults with prediabetes: A double-blind randomized clinical trial. Acta Diabetol 2018, 55, 1019-1028. [CrossRef] [PubMed]

26. Mancini, F.R.; Affret, A.; Dow, C.; Balkau, B.; Bonnet, F.; Boutron-Ruault, M.C.; Fagherazzi, G. Dietary antioxidant capacity and risk of type 2 diabetes in the large prospective E3N-EPIC cohort. Diabetologia 2018, 61, 308-316. [CrossRef] [PubMed]

27. Palacios, T.; Vitetta, L.; Coulson, S.; Madigan, C.D.; Denyer, G.S.; Caterson, I.D. The effect of a novel probiotic on metabolic biomarkers in adults with prediabetes and recently diagnosed type 2 diabetes mellitus: Study protocol for a randomized controlled trial. Trials 2017, 18, 7. [CrossRef]

28. Pandey, K.B.; Rizvi, S.I. Plant polyphenols as dietary antioxidants in human health and disease. Oxid. Med. Cell Longev. 2009, 2, 270-278. [CrossRef]

29. van der Schaft, N.; Schoufour, J.D.; Nano, J.; Kiefte-de Jong, J.C.; Muka, T.; Sijbrands, E.J.G.; Ikram, M.A.; Franco, O.H.; Voortman, T. Dietary antioxidant capacity and risk of type 2 diabetes mellitus, prediabetes and insulin resistance: The Rotterdam Study. Eur. J. Epidemiol. 2019, 34, 853-861. [CrossRef]

30. Stote, K.S.; Sweeney, M.I.; Kean, T.; Baer, D.J.; Novotny, J.A.; Shakerley, N.L.; Chandrasekaran, A.; Carrico, P.M.; Melendez, J.A.; Gottschall-Pass, K.T. The effects of $100 \%$ wild blueberry (Vaccinium angustifolium) juice consumption on cardiometablic biomarkers: A randomized, placebo-controlled, crossover trial in adults with increased risk for type 2 diabetes. BMC Nutr. 2017, 3, 45. [CrossRef]

31. Stull, A.J.; Cash, K.C.; Johnson, W.D.; Champagne, C.M.; Cefalu, W.T. Bioactives in blueberries improve insulin sensitivity in obese, insulin-resistant men and women. J. Nutr. 2010, 140, 1764-1768. [CrossRef]

32. Si, X.; Tian, J.; Shu, C.; Wang, Y.; Gong, E.; Zhang, Y.; Zhang, W.; Cui, H.; Li, B. Serum Ceramide Reduction by Blueberry Anthocyanin-Rich Extract Alleviates Insulin Resistance in Hyperlipidemia Mice. J. Agric. Food Chem. 2020, 68, 8185-8194. [CrossRef]

33. Guo, J.; Han, X.; Tan, H.; Huang, W.; You, Y.; Zhan, J. Blueberry Extract Improves Obesity through Regulation of the Gut Microbiota and Bile Acids via Pathways Involving FXR and TGR5. iScience 2019, 19, 676-690. [CrossRef] [PubMed]

34. Jiao, X.; Wang, Y.; Lin, Y.; Lang, Y.; Li, E.; Zhang, X.; Zhang, Q.; Feng, Y.; Meng, X.; Li, B. Blueberry polyphenols extract as a potential prebiotic with anti-obesity effects on C57BL/6J mice by modulating the gut microbiota. J. Nutr. Biochem. 2019, 64, 88-100. [CrossRef]

35. Rodriguez-Daza, M.C.; Roquim, M.; Dudonne, S.; Pilon, G.; Levy, E.; Marette, A.; Roy, D.; Desjardins, Y. Berry Polyphenols and Fibers Modulate Distinct Microbial Metabolic Functions and Gut Microbiota Enterotype-Like Clustering in Obese Mice. Front. Microbiol. 2020, 11, 2032. [CrossRef]

36. Zhuge, Q.; Zhang, Y.; Liu, B.; Wu, M. Blueberry polyphenols play a preventive effect on alcoholic fatty liver disease C57BL/6J mice by promoting autophagy to accelerate lipolysis to eliminate excessive TG accumulation in hepatocytes. Ann. Palliat Med. 2020, 9, 1045-1054. [CrossRef]

37. Kahn, S.E. The relative contributions of insulin resistance and beta-cell dysfunction to the pathophysiology of Type 2 diabetes. Diabetologia 2003, 46, 3-19. [CrossRef]

38. Cerf, M.E. Beta cell dysfunction and insulin resistance. Front. Endocrinol. 2013, 4, 37. [CrossRef] [PubMed] 
39. Henriksen, E.J.; Diamond-Stanic, M.K.; Marchionne, E.M. Oxidative stress and the etiology of insulin resistance and type 2 diabetes. Free Radic. Biol. Med. 2011, 51, 993-999. [CrossRef] [PubMed]

40. Pradhan, A.D.; Manson, J.E.; Rifai, N.; Buring, J.E.; Ridker, P.M. C-reactive protein, interleukin 6, and risk of developing type 2 diabetes mellitus. JAMA 2001, 286, 327-334. [CrossRef] [PubMed]

41. Spranger, J.; Kroke, A.; Mohlig, M.; Hoffmann, K.; Bergmann, M.M.; Ristow, M.; Boeing, H.; Pfeiffer, A.F. Inflammatory cytokines and the risk to develop type 2 diabetes: Results of the prospective population-based European Prospective Investigation into Cancer and Nutrition (EPIC)-Potsdam Study. Diabetes 2003, 52, 812-817. [CrossRef]

42. Bechmann, L.P.; Hannivoort, R.A.; Gerken, G.; Hotamisligil, G.S.; Trauner, M.; Canbay, A. The interaction of hepatic lipid and glucose metabolism in liver diseases. J. Hepatol. 2012, 56, 952-964. [CrossRef] [PubMed]

43. Nguyen, P.; Leray, V.; Diez, M.; Serisier, S.; Le Bloc'h, J.; Siliart, B.; Dumon, H. Liver lipid metabolism. J. Anim. Physiol. Anim. Nutr. 2008, 92, 272-283. [CrossRef] [PubMed]

44. Cohen, J.C.; Horton, J.D.; Hobbs, H.H. Human fatty liver disease: Old questions and new insights. Science 2011, 332, 1519-1523. [CrossRef] [PubMed]

45. Friedman, S.L.; Neuschwander-Tetri, B.A.; Rinella, M.; Sanyal, A.J. Mechanisms of NAFLD development and therapeutic strategies. Nat. Med. 2018, 24, 908-922. [CrossRef] [PubMed]

46. Anstee, Q.M.; Targher, G.; Day, C.P. Progression of NAFLD to diabetes mellitus, cardiovascular disease or cirrhosis. Nat. Rev. Gastroenterol. Hepatol. 2013, 10, 330-344. [CrossRef] [PubMed]

47. Samuel, V.T.; Liu, Z.X.; Qu, X.; Elder, B.D.; Bilz, S.; Befroy, D.; Romanelli, A.J.; Shulman, G.I. Mechanism of hepatic insulin resistance in non-alcoholic fatty liver disease. J. Biol. Chem. 2004, 279, 32345-32353. [CrossRef]

48. Stefan, N.; Hennige, A.M.; Staiger, H.; Machann, J.; Schick, F.; Krober, S.M.; Machicao, F.; Fritsche, A.; Haring, H.U. Alpha2Heremans-Schmid glycoprotein/fetuin-A is associated with insulin resistance and fat accumulation in the liver in humans. Diabetes Care 2006, 29, 853-857. [CrossRef]

49. Brown, J.M.; Hazen, S.L. The gut microbial endocrine organ: Bacterially derived signals driving cardiometabolic diseases. Annu. Rev. Med. 2015, 66, 343-359. [CrossRef]

50. Fan, Y.; Pedersen, O. Gut microbiota in human metabolic health and disease. Nat. Rev. Microbiol. 2021, 19, 55-71. [CrossRef]

51. Fernandes, R.; Viana, S.D.; Nunes, S.; Reis, F. Diabetic gut microbiota dysbiosis as an inflammaging and immunosenescence condition that fosters progression of retinopathy and nephropathy. Biochim. Biophys. Acta Mol. Basis Dis. 2019, 1865, $1876-1897$. [CrossRef]

52. Singer-Englar, T.; Barlow, G.; Mathur, R. Obesity, diabetes, and the gut microbiome: An updated review. Expert Rev. Gastroenterol. Hepatol. 2019, 13, 3-15. [CrossRef]

53. Mendes-Soares, H.; Raveh-Sadka, T.; Azulay, S.; Edens, K.; Ben-Shlomo, Y.; Cohen, Y.; Ofek, T.; Bachrach, D.; Stevens, J.; Colibaseanu, D.; et al. Assessment of a Personalized Approach to Predicting Postprandial Glycemic Responses to Food Among Individuals Without Diabetes. JAMA Netw. Open 2019, 2, e188102. [CrossRef] [PubMed]

54. Zeevi, D.; Korem, T.; Zmora, N.; Israeli, D.; Rothschild, D.; Weinberger, A.; Ben-Yacov, O.; Lador, D.; Avnit-Sagi, T.; Lotan-Pompan, M.; et al. Personalized Nutrition by Prediction of Glycemic Responses. Cell 2015, 163, 1079-1094. [CrossRef] [PubMed]

55. Allin, K.H.; Tremaroli, V.; Caesar, R.; Jensen, B.A.H.; Damgaard, M.T.F.; Bahl, M.I.; Licht, T.R.; Hansen, T.H.; Nielsen, T.; Dantoft, T.M.; et al. Aberrant intestinal microbiota in individuals with prediabetes. Diabetologia 2018, 61, 810-820. [CrossRef] [PubMed]

56. Forslund, K.; Hildebrand, F.; Nielsen, T.; Falony, G.; Le Chatelier, E.; Sunagawa, S.; Prifti, E.; Vieira-Silva, S.; Gudmundsdottir, V.; Pedersen, H.K.; et al. Disentangling type 2 diabetes and metformin treatment signatures in the human gut microbiota. Nature 2015, 528, 262-266. [CrossRef] [PubMed]

57. Karlsson, F.H.; Tremaroli, V.; Nookaew, I.; Bergstrom, G.; Behre, C.J.; Fagerberg, B.; Nielsen, J.; Backhed, F. Gut metagenome in European women with normal, impaired and diabetic glucose control. Nature 2013, 498, 99-103. [CrossRef]

58. Qin, J.; Li, Y.; Cai, Z.; Li, S.; Zhu, J.; Zhang, F.; Liang, S.; Zhang, W.; Guan, Y.; Shen, D.; et al. A metagenome-wide association study of gut microbiota in type 2 diabetes. Nature 2012, 490, 55-60. [CrossRef]

59. Huang, W.; Yao, L.; He, X.; Wang, L.; Li, M.; Yang, Y.; Wan, C. Hypoglycemic activity and constituents analysis of blueberry (Vaccinium corymbosum) fruit extracts. Diabetes Metab. Syndr. Obes. 2018, 11, 357-366. [CrossRef]

60. Michalska, A.; Lysiak, G. Bioactive Compounds of Blueberries: Post-Harvest Factors Influencing the Nutritional Value of Products. Int. J. Mol. Sci. 2015, 16, 18642-18663. [CrossRef]

61. Esquivel-Alvarado, D.; Munoz-Arrieta, R.; Alfaro-Viquez, E.; Madrigal-Carballo, S.; Krueger, C.G.; Reed, J.D. Composition of Anthocyanins and Proanthocyanidins in Three Tropical Vaccinium Species from Costa Rica. J. Agric. Food Chem. 2020, 68, 2872-2879. [CrossRef]

62. Routray, W.; Orsat, V. Blueberries and Their Anthocyanins: Factors Affecting Biosynthesis and Properties. Compr. Rev. Food Sci. Food Saf. 2011, 10, 303-320. [CrossRef]

63. Bujor, O.C.; Le Bourvellec, C.; Volf, I.; Popa, V.I.; Dufour, C. Seasonal variations of the phenolic constituents in bilberry (Vaccinium myrtillus L.) leaves, stems and fruits, and their antioxidant activity. Food Chem. 2016, 213, 58-68. [CrossRef] [PubMed]

64. Lohachoompol, V.; Srzednicki, G.; Craske, J. The Change of Total Anthocyanins in Blueberries and Their Antioxidant Effect After Drying and Freezing. J. Biomed. Biotechnol. 2004, 2004, 248-252. [CrossRef]

65. Skrovankova, S.; Sumczynski, D.; Mlcek, J.; Jurikova, T.; Sochor, J. Bioactive Compounds and Antioxidant Activity in Different Types of Berries. Int. J. Mol. Sci. 2015, 16, 24673-24706. [CrossRef] [PubMed] 
66. Basu, A. Role of Berry Bioactive Compounds on Lipids and Lipoproteins in Diabetes and Metabolic Syndrome. Nutrients 2019, 11, 1983. [CrossRef]

67. Johnson, M.H.; Wallig, M.; Luna Vital, D.A.; de Mejia, E.G. Alcohol-free fermented blueberry-blackberry beverage phenolic extract attenuates diet-induced obesity and blood glucose in C57BL/6J mice. J. Nutr. Biochem. 2016, 31, 45-59. [CrossRef]

68. Li, H.; Park, H.M.; Ji, H.S.; Han, J.; Kim, S.K.; Park, H.Y.; Jeong, T.S. Phenolic-enriched blueberry-leaf extract attenuates glucose homeostasis, pancreatic beta-cell function, and insulin sensitivity in high-fat diet-induced diabetic mice. Nutr. Res. 2020, 73, 83-96. [CrossRef]

69. Correa-Betanzo, J.; Padmanabhan, P.; Corredig, M.; Subramanian, J.; Paliyath, G. Complex formation of blueberry (Vaccinium angustifolium) anthocyanins during freeze-drying and its influence on their biological activity. J. Agric. Food Chem. 2015, 63, 2935-2946. [CrossRef]

70. Martineau, L.C.; Couture, A.; Spoor, D.; Benhaddou-Andaloussi, A.; Harris, C.; Meddah, B.; Leduc, C.; Burt, A.; Vuong, T.; Mai Le, P.; et al. Anti-diabetic properties of the Canadian lowbush blueberry Vaccinium angustifolium Ait. Phytomedicine 2006, 13, 612-623. [CrossRef]

71. Aksic, M.F.; Tosti, T.; Sredojevic, M.; Milivojevic, J.; Meland, M.; Natic, M. Comparison of Sugar Profile between Leaves and Fruits of Blueberry and Strawberry Cultivars Grown in Organic and Integrated Production System. Plants 2019, 8, 205. [CrossRef] [PubMed]

72. Miller, K.; Feucht, W.; Schmid, M. Bioactive Compounds of Strawberry and Blueberry and Their Potential Health Effects Based on Human Intervention Studies: A Brief Overview. Nutrients 2019, 11, 1510. [CrossRef]

73. Silva, S.; Costa, E.M.; Veiga, M.; Morais, R.M.; Calhau, C.; Pintado, M. Health promoting properties of blueberries: A review. Crit. Rev. Food Sci. Nutr. 2020, 60, 181-200. [CrossRef] [PubMed]

74. Beckman, C.H. Phenolic-storing cells: Keys to programmed cell death and periderm formation in wilt disease resistance and in general defence responses in plants? Physiol. Mol. Plant. Pathol. 2000, 57, 101-110. [CrossRef]

75. Pietta, P.; Minoggio, M.; Bramati, L. Plant Polyphenols: Structure, Occurrence and Bioactivity. In Studies in Natural Products Chemistry; Rahman, A.-U., Ed.; Elsevier: Amsterdam, The Netherlands, 2003; Volume 28, pp. 257-312.

76. Durazzo, A.; Lucarini, M.; Souto, E.B.; Cicala, C.; Caiazzo, E.; Izzo, A.A.; Novellino, E.; Santini, A. Polyphenols: A concise overview on the chemistry, occurrence, and human health. Phytother. Res. 2019, 33, 2221-2243. [CrossRef]

77. Riihinen, K.; Jaakola, L.; Karenlampi, S.; Hohtola, A. Organ-specific distribution of phenolic compounds in bilberry (Vaccinium myrtillus) and 'northblue' blueberry (Vaccinium corymbosum x V. angustifolium). Food Chem. 2008, 110, 156-160. [CrossRef]

78. Shahidi, F.; Yeo, J.D. Insoluble-Bound Phenolics in Food. Molecules 2016, 21, 1216. [CrossRef]

79. Aragonès, G.; Danesi, F.; Del Rio, D.; Mena, P. The importance of studying cell metabolism when testing the bioactivity of phenolic compounds. Trends Food Sci. Technol. 2017, 69, 230-242. [CrossRef]

80. Correa-Betanzo, J.; Allen-Vercoe, E.; McDonald, J.; Schroeter, K.; Corredig, M.; Paliyath, G. Stability and biological activity of wild blueberry (Vaccinium angustifolium) polyphenols during simulated in vitro gastrointestinal digestion. Food Chem. 2014, 165, 522-531. [CrossRef]

81. Santhakumar, A.B.; Battino, M.; Alvarez-Suarez, J.M. Dietary polyphenols: Structures, bioavailability and protective effects against atherosclerosis. Food Chem. Toxicol. 2018, 113, 49-65. [CrossRef]

82. Teng, H.; Chen, L. Polyphenols and bioavailability: An update. Crit. Rev. Food Sci. Nutr. 2019, 59, 2040-2051. [CrossRef]

83. Luca, S.V.; Macovei, I.; Bujor, A.; Miron, A.; Skalicka-Wozniak, K.; Aprotosoaie, A.C.; Trifan, A. Bioactivity of dietary polyphenols: The role of metabolites. Crit. Rev. Food Sci. Nutr. 2020, 60, 626-659. [CrossRef] [PubMed]

84. Scalbert, A.; Morand, C.; Manach, C.; Remesy, C. Absorption and metabolism of polyphenols in the gut and impact on health. Biomed. Pharm. 2002, 56, 276-282. [CrossRef]

85. Zhong, S.; Sandhu, A.; Edirisinghe, I.; Burton-Freeman, B. Characterization of Wild Blueberry Polyphenols Bioavailability and Kinetic Profile in Plasma over 24-h Period in Human Subjects. Mol. Nutr. Food Res. 2017, 61. [CrossRef] [PubMed]

86. Alqurashi, R.M.; Alarifi, S.N.; Walton, G.E.; Costabile, A.F.; Rowland, I.R.; Commane, D.M. In vitro approaches to assess the effects of acai (Euterpe oleracea) digestion on polyphenol availability and the subsequent impact on the faecal microbiota. Food Chem. 2017, 234, 190-198. [CrossRef]

87. Jakobek, L.; Matić, P. Non-covalent dietary fiber-Polyphenol interactions and their influence on polyphenol bioaccessibility. Trends Food Sci. Technol. 2019, 83, 235-247. [CrossRef]

88. Kumar Singh, A.; Cabral, C.; Kumar, R.; Ganguly, R.; Kumar Rana, H.; Gupta, A.; Rosaria Lauro, M.; Carbone, C.; Reis, F.; Pandey, A.K. Beneficial Effects of Dietary Polyphenols on Gut Microbiota and Strategies to Improve Delivery Efficiency. Nutrients 2019, 11, 2216. [CrossRef]

89. Russell, W.R.; Labat, A.; Scobbie, L.; Duncan, S.H. Availability of blueberry phenolics for microbial metabolism in the colon and the potential inflammatory implications. Mol. Nutr. Food Res. 2007, 51, 726-731. [CrossRef]

90. Yi, W.; Fischer, J.; Krewer, G.; Akoh, C.C. Phenolic compounds from blueberries can inhibit colon cancer cell proliferation and induce apoptosis. J. Agric. Food Chem. 2005, 53, 7320-7329. [CrossRef]

91. Liu, W.; Mao, Y.; Schoenborn, J.; Wang, Z.; Tang, G.; Tang, X. Whole blueberry protects pancreatic beta-cells in diet-induced obese mouse. Nutr. Metab. 2019, 16,34. [CrossRef]

92. Farhat, B.; Almelkar, A.; Ramachandran, K.; Williams, S.J.; Huang, H.H.; Zamierowksi, D.; Novikova, L.; Stehno-Bittel, L. Small human islets comprised of more beta-cells with higher insulin content than large islets. Islets 2013, 5, 87-94. [CrossRef] 
93. Sidorova, Y.; Shipelin, V.; Mazo, V.; Zorin, S.; Petrov, N.; Kochetkova, A. Hypoglycemic and hypolipidemic effect of Vaccinium myrtillus L. leaf and Phaseolus vulgaris L. seed coat extracts in diabetic rats. Nutrition 2017, 41, 107-112. [CrossRef] [PubMed]

94. Hanhineva, K.; Torronen, R.; Bondia-Pons, I.; Pekkinen, J.; Kolehmainen, M.; Mykkanen, H.; Poutanen, K. Impact of dietary polyphenols on carbohydrate metabolism. Int. J. Mol. Sci. 2010, 11, 1365-1402. [CrossRef] [PubMed]

95. Johnson, M.H.; Lucius, A.; Meyer, T.; de Mejia, E.G. Cultivar evaluation and effect of fermentation on antioxidant capacity and in vitro inhibition of alpha-amylase and alpha-glucosidase by highbush blueberry (Vaccinium corombosum). J. Agric. Food Chem. 2011, 59, 8923-8930. [CrossRef] [PubMed]

96. Pranprawit, A.; Heyes, J.A.; Molan, A.L.; Kruger, M.C. Antioxidant Activity and Inhibitory Potential of Blueberry Extracts Against Key Enzymes Relevant for Hyperglycemia. J. Food Biochem. 2015, 39, 109-118. [CrossRef]

97. Casedas, G.; Les, F.; Gomez-Serranillos, M.P.; Smith, C.; Lopez, V. Anthocyanin profile, antioxidant activity and enzyme inhibiting properties of blueberry and cranberry juices: A comparative study. Food Funct. 2017, 8, 4187-4193. [CrossRef] [PubMed]

98. Fan, J.; Johnson, M.H.; Lila, M.A.; Yousef, G.; de Mejia, E.G. Berry and Citrus Phenolic Compounds Inhibit Dipeptidyl Peptidase IV: Implications in Diabetes Management. Evid. Based Complement. Altern. Med. 2013, 2013, 479505. [CrossRef]

99. Johnson, M.H.; de Mejia, E.G. Phenolic Compounds from Fermented Berry Beverages Modulated Gene and Protein Expression To Increase Insulin Secretion from Pancreatic beta-Cells in Vitro. J. Agric. Food Chem. 2016, 64, 2569-2581. [CrossRef]

100. Zhang, S.; Zhang, Z.Y. PTP1B as a drug target: Recent developments in PTP1B inhibitor discovery. Drug Discov. Today 2007, 12, 373-381. [CrossRef]

101. Tian, J.L.; Liao, X.J.; Wang, Y.H.; Si, X.; Shu, C.; Gong, E.S.; Xie, X.; Ran, X.L.; Li, B. Identification of Cyanidin-3-arabinoside Extracted from Blueberry as a Selective Protein Tyrosine Phosphatase 1B Inhibitor. J. Agric. Food Chem. 2019, 67, 13624-13634. [CrossRef]

102. Nachar, A.; Eid, H.M.; Vinqvist-Tymchuk, M.; Vuong, T.; Kalt, W.; Matar, C.; Haddad, P.S. Phenolic compounds isolated from fermented blueberry juice decrease hepatocellular glucose output and enhance muscle glucose uptake in cultured murine and human cells. BMC Complement. Altern. Med. 2017, 17, 138. [CrossRef] [PubMed]

103. Vendrame, S.; Zhao, A.; Merrow, T.; Klimis-Zacas, D. The effects of wild blueberry consumption on plasma markers and gene expression related to glucose metabolism in the obese Zucker rat. J. Med. Food 2015, 18, 619-624. [CrossRef] [PubMed]

104. Hoggard, N.; Cruickshank, M.; Moar, K.M.; Bestwick, C.; Holst, J.J.; Russell, W.; Horgan, G. A single supplement of a standardised bilberry (Vaccinium myrtillus L.) extract (36\% wet weight anthocyanins) modifies glycaemic response in individuals with type 2 diabetes controlled by diet and lifestyle. J. Nutr. Sci. 2013, 2, e22. [CrossRef]

105. Stote, K.S.; Wilson, M.M.; Hallenbeck, D.; Thomas, K.; Rourke, J.M.; Sweeney, M.I.; Gottschall-Pass, K.T.; Gosmanov, A.R. Effect of Blueberry Consumption on Cardiometabolic Health Parameters in Men with Type 2 Diabetes: An 8-Week, Double-Blind, Randomized, Placebo-Controlled Trial. Curr. Dev. Nutr. 2020, 4, nzaa030. [CrossRef]

106. Stull, A.J. Blueberries' Impact on Insulin Resistance and Glucose Intolerance. Antioxidants 2016, 5, 44. [CrossRef]

107. Curtis, P.J.; van der Velpen, V.; Berends, L.; Jennings, A.; Feelisch, M.; Umpleby, A.M.; Evans, M.; Fernandez, B.O.; Meiss, M.S.; Minnion, M.; et al. Blueberries improve biomarkers of cardiometabolic function in participants with metabolic syndrome-results from a 6-month, double-blind, randomized controlled trial. Am. J. Clin. Nutr. 2019, 109, 1535-1545. [CrossRef] [PubMed]

108. Sobolev, A.P.; Ciampa, A.; Ingallina, C.; Mannina, L.; Capitani, D.; Ernesti, I.; Maggi, E.; Businaro, R.; Del Ben, M.; Engel, P.; et al. Blueberry-Based Meals for Obese Patients with Metabolic Syndrome: A Multidisciplinary Metabolomic Pilot Study. Metabolites 2019, 9, 138. [CrossRef] [PubMed]

109. Nair, A.R.; Mariappan, N.; Stull, A.J.; Francis, J. Blueberry supplementation attenuates oxidative stress within monocytes and modulates immune cell levels in adults with metabolic syndrome: A randomized, double-blind, placebo-controlled trial. Food Funct. 2017, 8, 4118-4128. [CrossRef] [PubMed]

110. Basu, A.; Du, M.; Leyva, M.J.; Sanchez, K.; Betts, N.M.; Wu, M.; Aston, C.E.; Lyons, T.J. Blueberries decrease cardiovascular risk factors in obese men and women with metabolic syndrome. J. Nutr. 2010, 140, 1582-1587. [CrossRef]

111. Li, D.; Zhang, Y.; Liu, Y.; Sun, R.; Xia, M. Purified anthocyanin supplementation reduces dyslipidemia, enhances antioxidant capacity, and prevents insulin resistance in diabetic patients. J. Nutr. 2015, 145, 742-748. [CrossRef] [PubMed]

112. Pastor, R.F.; Gonzalez, E.; Cassini, M.S.; Pastor, I.; Sauré, M.; Saavedra, E.; Simman Menem, M.I.; Dragos, S.; Iermoli, R.H. Blueberry Extract Reduces Oxidative Stress in Patients with Metabolic Syndrome. J. Life Sci. 2016, 10, $145-152$.

113. Istek, N.; Gurbuz, O. Investigation of the impact of blueberries on metabolic factors influencing health. J. Funct. Foods 2017, 38, 298-307. [CrossRef]

114. Zhang, P.W.; Chen, F.X.; Li, D.; Ling, W.H.; Guo, H.H. A CONSORT-compliant, randomized, double-blind, placebo-controlled pilot trial of purified anthocyanin in patients with nonalcoholic fatty liver disease. Medicine 2015, 94, e758. [CrossRef]

115. Vendrame, S.; Guglielmetti, S.; Riso, P.; Arioli, S.; Klimis-Zacas, D.; Porrini, M. Six-week consumption of a wild blueberry powder drink increases bifidobacteria in the human gut. J. Agric. Food Chem. 2011, 59, 12815-12820. [CrossRef]

116. Ntemiri, A.; Ghosh, T.S.; Gheller, M.E.; Tran, T.T.T.; Blum, J.E.; Pellanda, P.; Vlckova, K.; Neto, M.C.; Howell, A.; Thalacker-Mercer, A.; et al. Whole Blueberry and Isolated Polyphenol-Rich Fractions Modulate Specific Gut Microbes in an In Vitro Colon Model and in a Pilot Study in Human Consumers. Nutrients 2020, 12, 2800. [CrossRef] [PubMed]

117. Borges, G.; Degeneve, A.; Mullen, W.; Crozier, A. Identification of flavonoid and phenolic antioxidants in black currants, blueberries, raspberries, red currants, and cranberries. J. Agric. Food Chem. 2010, 58, 3901-3909. [CrossRef] [PubMed] 
118. Zheng, W.; Wang, S.Y. Oxygen radical absorbing capacity of phenolics in blueberries, cranberries, chokeberries, and lingonberries. J. Agric. Food Chem. 2003, 51, 502-509. [CrossRef] [PubMed]

119. Cho, M.J.; Howard, L.R.; Prior, R.L.; Clark, J.R. Flavonoid glycosides and antioxidant capacity of various blackberry, blueberry and red grape genotypes determined by high-performance liquid chromatography/mass spectrometry. J. Sci. Food Agric. 2004, 84, 1771-1782. [CrossRef]

120. Sellappan, S.; Akoh, C.C.; Krewer, G. Phenolic compounds and antioxidant capacity of Georgia-grown blueberries and blackberries. J. Agric. Food Chem. 2002, 50, 2432-2438. [CrossRef]

121. Taruscio, T.G.; Barney, D.L.; Exon, J. Content and profile of flavanoid and phenolic acid compounds in conjunction with the antioxidant capacity for a variety of northwest Vaccinium berries. J. Agric. Food Chem. 2004, 52, 3169-3176. [CrossRef]

122. Luc, K.; Schramm-Luc, A.; Guzik, T.J.; Mikolajczyk, T.P. Oxidative stress and inflammatory markers in prediabetes and diabetes. J. Physiol. Pharm. 2019, 70. [CrossRef]

123. Huang, W.; Yan, Z.; Li, D.; Ma, Y.; Zhou, J.; Sui, Z. Antioxidant and Anti-Inflammatory Effects of Blueberry Anthocyanins on High Glucose-Induced Human Retinal Capillary Endothelial Cells. Oxid. Med. Cell Longev. 2018, 2018, 1862462. [CrossRef] [PubMed]

124. Pereira, S.R.; Pereira, R.; Figueiredo, I.; Freitas, V.; Dinis, T.C.; Almeida, L.M. Comparison of anti-inflammatory activities of an anthocyanin-rich fraction from Portuguese blueberries (Vaccinium corymbosum L.) and 5-aminosalicylic acid in a TNBS-induced colitis rat model. PLoS ONE 2017, 12, e0174116. [CrossRef]

125. Cutler, B.R.; Gholami, S.; Chua, J.S.; Kuberan, B.; Anandh Babu, P.V. Blueberry metabolites restore cell surface glycosaminoglycans and attenuate endothelial inflammation in diabetic human aortic endothelial cells. Int. J. Cardiol. 2018, 261, 155-158. [CrossRef]

126. Vendrame, S.; Daugherty, A.; Kristo, A.S.; Klimis-Zacas, D. Wild blueberry (Vaccinium angustifolium)-enriched diet improves dyslipidaemia and modulates the expression of genes related to lipid metabolism in obese Zucker rats. Br. J. Nutr. 2014, 111, 194-200. [CrossRef]

127. Lee, S.; Keirsey, K.I.; Kirkland, R.; Grunewald, Z.I.; Fischer, J.G.; de La Serre, C.B. Blueberry Supplementation Influences the Gut Microbiota, Inflammation, and Insulin Resistance in High-Fat-Diet-Fed Rats. J. Nutr. 2018, 148, 209-219. [CrossRef]

128. DeFuria, J.; Bennett, G.; Strissel, K.J.; Perfield, J.W., 2nd; Milbury, P.E.; Greenberg, A.S.; Obin, M.S. Dietary blueberry attenuates whole-body insulin resistance in high fat-fed mice by reducing adipocyte death and its inflammatory sequelae. J. Nutr. 2009, 139, 1510-1516. [CrossRef]

129. Nair, A.R.; Elks, C.M.; Vila, J.; Del Piero, F.; Paulsen, D.B.; Francis, J. A blueberry-enriched diet improves renal function and reduces oxidative stress in metabolic syndrome animals: Potential mechanism of TLR4-MAPK signaling pathway. PLoS ONE 2014, 9, e111976. [CrossRef] [PubMed]

130. Nunes, S.; Viana, S.D.; Preguica, I.; Alves, A.; Fernandes, R.; Teodoro, J.S.; Figueirinha, A.; Salgueiro, L.; Silva, S.; Jarak, I.; et al. Blueberry Consumption Challenges Hepatic Mitochondrial Bioenergetics and Elicits Transcriptomics Reprogramming in Healthy Wistar Rats. Pharmaceutics 2020, 12, 1094. [CrossRef]

131. Kay, C.D.; Holub, B.J. The effect of wild blueberry (Vaccinium angustifolium) consumption on postprandial serum antioxidant status in human subjects. Br. J. Nutr. 2002, 88, 389-398. [CrossRef]

132. Mazza, G.; Kay, C.D.; Cottrell, T.; Holub, B.J. Absorption of anthocyanins from blueberries and serum antioxidant status in human subjects. J. Agric. Food Chem. 2002, 50, 7731-7737. [CrossRef] [PubMed]

133. Molan, A.L.; Lila, M.A.; Mawson, J. Satiety in rats following blueberry extract consumption induced by appetite-suppressing mechanisms unrelated to in vitro or in vivo antioxidant capacity. Food Chem. 2008, 107, 1039-1044. [CrossRef]

134. Pedersen, C.B.; Kyle, J.; Jenkinson, A.M.; Gardner, P.T.; McPhail, D.B.; Duthie, G.G. Effects of blueberry and cranberry juice consumption on the plasma antioxidant capacity of healthy female volunteers. Eur. J. Clin. Nutr. 2000, 54, 405-408. [CrossRef] [PubMed]

135. Serafini, M.; Testa, M.F.; Villano, D.; Pecorari, M.; van Wieren, K.; Azzini, E.; Brambilla, A.; Maiani, G. Antioxidant activity of blueberry fruit is impaired by association with milk. Free Radic. Biol. Med. 2009, 46, 769-774. [CrossRef]

136. Takikawa, M.; Inoue, S.; Horio, F.; Tsuda, T. Dietary anthocyanin-rich bilberry extract ameliorates hyperglycemia and insulin sensitivity via activation of AMP-activated protein kinase in diabetic mice. J. Nutr. 2010, 140, 527-533. [CrossRef] [PubMed]

137. Wang, Y.; Zhao, L.; Wang, D.; Huo, Y.; Ji, B. Anthocyanin-rich extracts from blackberry, wild blueberry, strawberry, and chokeberry: Antioxidant activity and inhibitory effect on oleic acid-induced hepatic steatosis in vitro. J. Sci. Food Agric. 2016, 96, 2494-2503. [CrossRef] [PubMed]

138. Bingul, I.; Basaran-Kucukgergin, C.; Tekkesin, M.S.; Olgac, V.; Dogru-Abbasoglu, S.; Uysal, M. Effect of blueberry pretreatment on diethylnitrosamine-induced oxidative stress and liver injury in rats. Environ. Toxicol. Pharm. 2013, 36, 529-538. [CrossRef]

139. Wu, J.; Li, M.; He, J.; Lv, K.; Wang, M.; Guan, W.; Liu, J.; Tao, Y.; Li, S.; Ho, C.T.; et al. Protective effect of pterostilbene on concanavalin A-induced acute liver injury. Food Funct. 2019, 10, 7308-7314. [CrossRef] [PubMed]

140. Li, Z.; Zhang, H.; Li, Y.; Chen, H.; Wang, C.; Wong, V.K.W.; Jiang, Z.; Zhang, W. Phytotherapy using blueberry leaf polyphenols to alleviate non-alcoholic fatty liver disease through improving mitochondrial function and oxidative defense. Phytomedicine 2020, 69, 153209. [CrossRef] [PubMed]

141. Asgary, S.; RafieianKopaei, M.; Sahebkar, A.; Shamsi, F.; Goli-malekabadi, N. Anti-hyperglycemic and anti-hyperlipidemic effects of Vaccinium myrtillus fruit in experimentally induced diabetes (antidiabetic effect of Vaccinium myrtillus fruit). J. Sci. Food Agric. 2016, 96, 764-768. [CrossRef] 
142. Zhu, J.; Zhou, M.; Zhao, X.; Mu, M.; Cheng, M. Blueberry, combined with probiotics, alleviates non-alcoholic fatty liver disease via IL-22-mediated JAK1/STAT3/BAX signaling. Food Funct. 2018, 9, 6298-6306. [CrossRef]

143. Chen, K.; Wei, X.; Zhang, J.; Pariyani, R.; Jokioja, J.; Kortesniemi, M.; Linderborg, K.M.; Heinonen, J.; Sainio, T.; Zhang, Y.; et al. Effects of Anthocyanin Extracts from Bilberry (Vaccinium myrtillus L.) and Purple Potato (Solanum tuberosum L. var. Synkea Sakari) on the Plasma Metabolomic Profile of Zucker Diabetic Fatty Rats. J. Agric. Food Chem. 2020, 68, 9436-9450. [CrossRef]

144. Bendokas, V.; Skemiene, K.; Trumbeckaite, S.; Stanys, V.; Passamonti, S.; Borutaite, V.; Liobikas, J. Anthocyanins: From plant pigments to health benefits at mitochondrial level. Crit. Rev. Food Sci. Nutr. 2020, 60, 3352-3365. [CrossRef] [PubMed]

145. Jiang, X.; Tang, X.; Zhang, P.; Liu, G.; Guo, H. Cyanidin-3-O-beta-glucoside protects primary mouse hepatocytes against high glucose-induced apoptosis by modulating mitochondrial dysfunction and the PI3K/Akt pathway. Biochem. Pharm. 2014, 90, 135-144. [CrossRef]

146. Ren, T.; Zhu, L.; Shen, Y.; Mou, Q.; Lin, T.; Feng, H. Protection of hepatocyte mitochondrial function by blueberry juice and probiotics via SIRT1 regulation in non-alcoholic fatty liver disease. Food Funct. 2019, 10, 1540-1551. [CrossRef]

147. Skates, E.; Overall, J.; DeZego, K.; Wilson, M.; Esposito, D.; Lila, M.A.; Komarnytsky, S. Berries containing anthocyanins with enhanced methylation profiles are more effective at ameliorating high fat diet-induced metabolic damage. Food Chem. Toxicol. 2018, 111, 445-453. [CrossRef] [PubMed]

148. Zhao, M.; Wang, P.; Zhu, Y.; Liu, X.; Hu, X.; Chen, F. The chemoprotection of a blueberry anthocyanin extract against the acrylamide-induced oxidative stress in mitochondria: Unequivocal evidence in mice liver. Food Funct. 2015, 6, $3006-3012$. [CrossRef] [PubMed]

149. Ferreira, F.M.; Peixoto, F.P.; Nunes, E.; Sena, C.; Seica, R.; Santos, M.S. Vaccinium myrtillus improves liver mitochondrial oxidative phosphorylation of diabetic Goto-Kakizaki rats. J. Med. Plants Res. 2010, 4, 692-696.

150. Davis, J.M.; Murphy, E.A.; Carmichael, M.D.; Davis, B. Quercetin increases brain and muscle mitochondrial biogenesis and exercise tolerance. Am. J. Physiol. Regul. Integr. Comp. Physiol. 2009, 296, R1071-R1077. [CrossRef] [PubMed]

151. Ren, T.; Huang, C.; Cheng, M. Dietary blueberry and bifidobacteria attenuate nonalcoholic fatty liver disease in rats by affecting SIRT1-mediated signaling pathway. Oxid. Med. Cell Longev. 2014, 2014, 469059. [CrossRef]

152. Morissette, A.; Kropp, C.; Songpadith, J.P.; Junges Moreira, R.; Costa, J.; Marine-Casado, R.; Pilon, G.; Varin, T.V.; Dudonne, S.; Boutekrabt, L.; et al. Blueberry proanthocyanidins and anthocyanins improve metabolic health through a gut microbiotadependent mechanism in diet-induced obese mice. Am. J. Physiol. Endocrinol. Metab. 2020, 318, E965-E980. [CrossRef]

153. Vendrame, S.; Daugherty, A.; Kristo, A.S.; Riso, P.; Klimis-Zacas, D. Wild blueberry (Vaccinium angustifolium) consumption improves inflammatory status in the obese Zucker rat model of the metabolic syndrome. J. Nutr. Biochem. 2013, 24, 1508-1512. [CrossRef]

154. Elks, C.M.; Terrebonne, J.D.; Ingram, D.K.; Stephens, J.M. Blueberries improve glucose tolerance without altering body composition in obese postmenopausal mice. Obesity 2015, 23, 573-580. [CrossRef] [PubMed]

155. Wu, T.; Gao, Y.; Guo, X.; Zhang, M.; Gong, L. Blackberry and Blueberry Anthocyanin Supplementation Counteract High-Fat-DietInduced Obesity by Alleviating Oxidative Stress and Inflammation and Accelerating Energy Expenditure. Oxidative Med. Cell. Longev. 2018, 2018, 4051232. [CrossRef] [PubMed]

156. Zhong, H.; Abdullah; Deng, L.; Zhao, M.; Tang, J.; Liu, T.; Zhang, H.; Feng, F. Probiotic-fermented blueberry juice prevents obesity and hyperglycemia in high fat diet-fed mice in association with modulating the gut microbiota. Food Funct. 2020, 11, 9192-9207. [CrossRef] [PubMed]

157. Lavefve, L.; Howard, L.R.; Carbonero, F. Berry polyphenols metabolism and impact on human gut microbiota and health. Food Funct. 2020, 11, 45-65. [CrossRef]

158. Zhou, L.; Xie, M.; Yang, F.; Liu, J. Antioxidant activity of high purity blueberry anthocyanins and the effects on human intestinal microbiota. LWT 2020, 117, 108621. [CrossRef]

159. Bas-Bellver, C.; Andres, C.; Segui, L.; Barrera, C.; Jimenez-Hernandez, N.; Artacho, A.; Betoret, N.; Gosalbes, M.J. Valorization of Persimmon and Blueberry Byproducts to Obtain Functional Powders: In Vitro Digestion and Fermentation by Gut Microbiota. J. Agric. Food Chem. 2020, 68, 8080-8090. [CrossRef] [PubMed]

160. Molan, A.L.; Lila, M.A.; Mawson, J.; De, S. In vitro and in vivo evaluation of the prebiotic activity of water-soluble blueberry extracts. World J. Microbiol. Biotechnol. 2009, 25, 1243-1249. [CrossRef]

161. Guglielmetti, S.; Fracassetti, D.; Taverniti, V.; Del Bo, C.; Vendrame, S.; Klimis-Zacas, D.; Arioli, S.; Riso, P.; Porrini, M. Differential modulation of human intestinal bifidobacterium populations after consumption of a wild blueberry (Vaccinium angustifolium) drink. J. Agric. Food Chem. 2013, 61, 8134-8140. [CrossRef]

162. Rodriguez-Daza, M.C.; Daoust, L.; Boutkrabt, L.; Pilon, G.; Varin, T.; Dudonne, S.; Levy, E.; Marette, A.; Roy, D.; Desjardins, Y. Wild blueberry proanthocyanidins shape distinct gut microbiota profile and influence glucose homeostasis and intestinal phenotypes in high-fat high-sucrose fed mice. Sci. Rep. 2020, 10, 2217. [CrossRef]

163. Liu, H.Y.; Walden, T.B.; Cai, D.; Ahl, D.; Bertilsson, S.; Phillipson, M.; Nyman, M.; Holm, L. Dietary Fiber in Bilberry Ameliorates Pre-Obesity Events in Rats by Regulating Lipid Depot, Cecal Short-Chain Fatty Acid Formation and Microbiota Composition. Nutrients 2019, 11, 1350. [CrossRef]

164. Everard, A.; Belzer, C.; Geurts, L.; Ouwerkerk, J.P.; Druart, C.; Bindels, L.B.; Guiot, Y.; Derrien, M.; Muccioli, G.G.; Delzenne, N.M.; et al. Cross-talk between Akkermansia muciniphila and intestinal epithelium controls diet-induced obesity. Proc. Natl. Acad. Sci. USA 2013, 110, 9066-9071. [CrossRef] 
165. Shin, N.R.; Lee, J.C.; Lee, H.Y.; Kim, M.S.; Whon, T.W.; Lee, M.S.; Bae, J.W. An increase in the Akkermansia spp. population induced by metformin treatment improves glucose homeostasis in diet-induced obese mice. Gut 2014, 63, 727-735. [CrossRef] [PubMed]

166. Gomez-Gallego, C.; Pohl, S.; Salminen, S.; De Vos, W.M.; Kneifel, W. Akkermansia muciniphila: A novel functional microbe with probiotic properties. Benef. Microbes. 2016, 7, 571-584. [CrossRef] [PubMed]

167. Cheng, Y.; Tang, S.; Huang, Y.; Liang, F.; Fang, Y.; Pan, S.; Wu, T.; Xu, X. Lactobacillus casei-fermented blueberry pomace augments sIgA production in high-fat diet mice by improving intestinal microbiota. Food Funct. 2020, 11, 6552-6564. [CrossRef]

168. Yan, Z.; Yang, F.; Hong, Z.; Wang, S.; Jinjuan, Z.; Han, B.; Xie, R.; Leng, F.; Yang, Q. Blueberry Attenuates Liver Fibrosis, Protects Intestinal Epithelial Barrier, and Maintains Gut Microbiota Homeostasis. Can. J. Gastroenterol. Hepatol. 2019, $2019,5236149$. [CrossRef]

169. Cheng, Z.; Lin, J.; Gao, N.; Sun, X.; Meng, X.; Liu, R.; Liu, Y.; Wang, W.; Li, B.; Wang, Y. Blueberry malvidin-3-galactoside modulated gut microbial dysbiosis and microbial TCA cycle KEGG pathway disrupted in a liver cancer model induced by HepG2 cells. Food Sci. Hum. Wellness 2020, 9, 245-255. [CrossRef]

170. Rebello, C.J.; Burton, J.; Heiman, M.; Greenway, F.L. Gastrointestinal microbiome modulator improves glucose tolerance in overweight and obese subjects: A randomized controlled pilot trial. J. Diabetes Complicat. 2015, 29, 1272-1276. [CrossRef] [PubMed]

171. Priya, G. Management of prediabetes. J. Pak. Med. Assoc. 2018, 68, 669-671. [PubMed]

172. Tamrakar, A.K.; Maurya, C.K.; Rai, A.K. PTP1B inhibitors for type 2 diabetes treatment: A patent review (2011-2014). Expert Opin. Pat. 2014, 24, 1101-1115. [CrossRef] [PubMed]

173. Zhang, J.; Sun, L.; Dong, Y.; Fang, Z.; Nisar, T.; Zhao, T.; Wang, Z.C.; Guo, Y. Chemical compositions and alpha-glucosidase inhibitory effects of anthocyanidins from blueberry, blackcurrant and blue honeysuckle fruits. Food Chem. 2019, $299,125102$. [CrossRef]

174. Laiteerapong, N.; Ham, S.A.; Gao, Y.; Moffet, H.H.; Liu, J.Y.; Huang, E.S.; Karter, A.J. The Legacy Effect in Type 2 Diabetes: Impact of Early Glycemic Control on Future Complications (The Diabetes \& Aging Study). Diabetes Care 2019, 42, 416-426. [CrossRef] [PubMed]

175. Rodriguez-Gutierrez, R.; Gonzalez-Gonzalez, J.G.; Zuniga-Hernandez, J.A.; McCoy, R.G. Benefits and harms of intensive glycemic control in patients with type 2 diabetes. BMJ 2019, 367, 15887. [CrossRef] [PubMed] 